\title{
En kartläggning av det högerextrema nätverket på internet - strukturella mönster 2006-20II
}

\section{Ralf Wiederer}

SAMMANDRAG: Ralf Wiederers artikel analyserar utvecklingen hos den extrema högerns nätverk på internet genom att undersöka relationerna mellan olika gruppers och aktivisters webbsidor i form av hyperlänkar. Wiederer tar hjälp av social nätverksanalys för att studera strukturen hos dessa sammanslutningar på både nationell och internationell nivå. Hans data har genererats automatiskt med hjälp av robotar och sökmotorer, vilka tillåter framtagandet av stora mängder information utan validitetsförlust. Artikeln ger en kort teoretisk och metodologisk introduktion och summerar resultaten från en pilotstudie publicerad 2007. I en longitudinell fortsättning jämförs sedan dessa resultat med hur nätverksstrukturen såg ut 20II. Den longitudinella analysen indikerar att de högerextrema nätverken generellt är tätt sammanknutna och visar på en ökande sammanlänkning både inom och mellan nationella och ideologiska kluster.

NYCKELORD: högerextremism; nynazism; social nätverksanalys; sociala rörelser; internet; terrorism.

PUbLICERINGSHistorik: Översättning av artikeln "Mapping the Right-Wing Extremist Movement on the Internet - Structural Patterns 2006-20II" från den kommande antologin In the Tracks of Breivik. Far-Right Networks in Northern and Eastern Europe, Michael Minkenberg, Mats Deland \& David Payne (red.), LIT Verlag.

RALF WIEDERER är doktor från Universität Eichstätt-Ingolstadt och frilansforskare.

FÖRSLAG PÅ KÄLLANGIVELSE:

Wiederer, Ralf (2013) "En kartläggning av det högerextrema nätverket på internet strukturella mönster 2006-20II", i Det vita fältet II. Samtida forskning om högerextremism, specialnummer av Arkiv. Tidskrift för samhällsanalys, nr 2, s. IOI-I37.

DOI: http://dx.doi.org/IO.I3068/2000-6217.2.4

(C) original: Ralf Wiederer

(C) svensk version: Ralf Wiederer/Arkiv förlag \& tidskrift 2013

(publicerad I6 september 20I3)

Artikeln distribueras enligt en upphovsrättslicens från Creative Commons:

Erkännande-Ickekommersiell-IngaBearbetningar 3.0 Unported, som medger fri ickekommersiell användning och spridning i oförändrat skick så länge källan anges. 
Arkiv. Tidskrift för samhällsanalys är en sakkunniggranskad vetenskaplig tidskrift för samhällsvetenskap och historia. Samtliga artiklar publiceras fritt tillgängliga på:

$$
\text { www.tidskriftenarkiv.se }
$$

(beständig länk, DOI: http://dx.doi.org/IO.I3068/2000-62I7)

Den här artikeln finns tillgänglig i följande format:

PDF \& HTML: via beständig länk, DOI: http://dx.doi.org/IO.I3068/2000-6217.2.4 EPUB: ingår i e-boksutgåva av numret, ISBN: 978 9I 7924254 I TRYCK: ingår i bokutgåva av numret, ISBN: 978 9I 79242558

Grafisk utformning och sidnumrering är identisk i pdf och tryck.

Samtliga artiklar i nr 2 (2013), Det vita fältet II. Samtida forskning om högerextremism, nås via beständig länk, DoI: http://dx.doi.org/I0.13068/2000-6217.2 redaktion för numret: Mats Deland, Paul Fuehrer och Fredrik Hertzberg

Arkiv. Tidskrift för sambällsanalys ISSN: 2000-62I7 (för elektronisk resurs) ISSN: 2000-6225 (för tryckta nummer)

ges ut av

Stiftelsen Arkiv för främjande och spridning av samhällsvetenskaplig och historisk forskning

genom

Arkiv förlag \& tidskrift

Box 1559 SE-22I OI Lund BESÖK: L Gråbrödersg 3 c, ipg TEL: O46-I3 3920

ARKIV FÖRLAG: arkiv@arkiv.nu·www.arkiv.nu TIDSKRIFTEN ARKIV: red@tidskriftenarkiv.se · www.tidskriftenarkiv.se

ANSVARIg UTGIVARE \& CHEFREDAKTÖR: Sven Hort AdMinistrativ Redaktör: David Lindberg ReDAKTörer: Paavo Bergman, Lisa Kings, Zhanna Kravchenko 


\title{
En kartläggning av det högerextrema nätverket på internet - strukturella mönster 2006-20II
}

\author{
RALF WIEDERER
}

Informationsåldern har utan tvekan ändrat förutsättningarna för högerextrem aktivism. Internet har öppnat oräkneliga möjligheter för de högerextrema aktivisterna att organisera sig, nätverka, agitera och sälja sina varor. För att förstå strukturen och förändringarna hos rörelsen ska jag i den här artikeln systematiskt och i stor skala analysera spåren av deras internetaktivism.

För att kartlägga de nationella och internationella kontakter som förbinder organisationer, grupper och aktivister, kommer jag att analysera hyperlänkar mellan högerextrema webbsidor och det innehåll och den ideologi som exponeras på dessa sidor. Uppgifterna samlas in automatiskt med hjälp av robotar och webbspindlar, så att det blir möjligt att utvinna en stor mängd data på förhållandevis kort tid. Med hjälp av metoder som hämtats från social nätverksanalys kommer jag att försöka få fram rörelsens struktur och dynamik.

Artikeln inleds med en kortfattad teoretisk och metodologisk introduktion och en sammanfattning av resultaten från en pilotstudie som publicerades 2007. Efter det kommer jag att undersöka de förändringar som skett inom det högerextrema nätverket under de senaste fem åren.

Artikeln är en översättning av "Mapping the Right-Wing Extremist Movement on the Internet - Structural Patterns 2006-20II" från den kommande antologin, In the Tracks of Breivik. Far-Right Networks in Northern and Eastern Europe, Michael Minkenberg, Mats Deland \& David Payne (red.), LIT Verlag. Den publiceras här med tillstånd av författaren. 


\section{Högerextremisters användning av datorförmedlad kommunikation}

Nästan alla moderna samhällen måste hantera problem med främlingsfientliga attityder och våld. Under de senaste decennierna har den snabba och vittgående sociala moderniseringen, omdefinieringen av de nationella strukturerna och globaliseringen frambringat en diversifierad, varierad och motsägelsefull utveckling av högerextremismen och det våld som den för med sig (Heitmeyer 2002, s. 50I). Särskilt i USA och i Europa har forskare observerat en ökande högerextrem mobilisering sedan det tidiga 1990-talet (Kitschelt \& McGann 1995; Koopmans 1996; Minkenberg 1998).

Det har länge diskuterats om den högerextrema miljön kan förstås som en social rörelse. Samtidigt har observatörer rapporterat om åtminstone rörelseliknande strukturer och, allra viktigast, att åtskilliga högerextrema aktivister och aktivistgrupper uppfattar sig själva som delar av eller åtminstone på väg att bli delar av en social rörelse (Rucht 2002). Sociala rörelser är

diffusa fält för kollektiv handling där aktiviteter påverkar varandra och där aktörernas handlingsmönster utvecklas interaktivt över tid. Enskilda aktivister och rörelser ägnar sig åt strategiska interaktioner där de svarar på varandras verksamheter (Oliver \& Myers 2000, s. 2).

Därför är rörelser oformliga, svagt strukturerade sociala enheter - associativa och samarbetande nätverk av individuella och kollektiva aktörer (Passy 2003).

Möjligheter till kommunikation över internet har på ett betydande sätt förändrat de mest moderna sociala rörelsernas strategi och struktur, eftersom "taktikerna för att nå ut med sitt budskap växlar med situationen, de inblandade och kulturen" (Blumer 1953 [1939], s. 205). Utan tvivel har de nya medierna påverkat, och fortsätter att påverka, strukturen hos de ganska löst organiserade aktivistnätverken. De diffusa nätverken av individer, grupper, organisationer, publicister och försäljare kan lätt komma i kontakt med varandra eller upprätthålla kontakter med hjälp av internet, det är en ny fas 
[...] som karakteriseras av förändringar i organiseringsstrukturer, ideologier, taktiker och kommunikationsstrategier [...] Förändringarna inbegriper ett skifte i formerna för organisering, från hierarkiska strukturer till nätverksorganisering av medlemmar utspridda i olika länder, på skilda geografiska platser och i virtuella nätverk; ett ideologiskt skifte från politiska till mer religiösa motiv; ett taktikskifte där fokus flyttas från lättillgängliga mål till en global spridning av mål; ett organiseringsskifte från centraliserad styrning till virtuell styrning; och slutligen ett skifte i kommunikationsstrategier, från att vara beroende av traditionella medier till att förlita sig på internetbaserade grupper [...] (Reid \& Chen 2007, s. I77-I78).

Framstegen inom de nya informations- och kommunikationsteknikerna, särskilt den snabba utvecklingen av kommunikation genom internet, innebär omvälvande förändringar för den marginaliserade högerextrema rörelsen. Tidigare saknade den i hög utsträckning tillgång till etablerade medier. Internet erbjuder en mängd möjligheter för nätverksbyggande och för att sprida propaganda. Det tillåter konversationer i det fördolda och individuell agitation. Det kan användas för att sälja varor och för att koordinera kollektiva aktioner. Eftersom den högerextrema rörelsen är en så kallad ytterlighetsrörelse, som i allmänhet saknar social uppbackning och vars ideologi, symbolik och handlingar befinner sig på gränsen till det lagliga, har nätaktivismen öppnat oanade möjligheter (Burris m.f. 2000, s. 224).

Samtidigt förfogar högerextremister över hela världen över tusentals webbsidor. Det har uppskattats att det finns omkring I ooo webbsidor som tillhör tyska aktivister (Bundesministerium des Innern 20I0, s. 59). Flera hundra webbsidor av motsvarande slag rapporteras och övervakas i USA (Simon Wiesenthal Center 2002). Bortsett från webbsidor använder aktivisterna e-post, sändlistor och internetforum. De använder sig av e-handel, sänder radio- och tv-program och ställer musiksamlingar till förfogande (Zhou m.fl. 2005).

Det finns sedan länge vetenskapliga studier av hur de rasistiska och högerextrema grupperna världen över använder internet (Ackland \& Gibson 2005; Levin 2002; Whine 2004). Det finns oräkneliga publikationer om användningen, men empiriskt handlar det för det mesta 
om fallstudier, kvantitativa ansatser är ovanliga. ${ }^{\mathrm{I}}$ Det är inte enkelt att utifrån dessa fall skapa sig en överblick över rörelsen som helhet. Den forskning som systematiskt analyserar högerextrema webbsammanhang och det innehåll de publicerar har inte mer än inletts (Burris m.f. 2000; Gerstenfeld m.fl. 2003; Reid \& Chen 2007; Tateo 2005; Zhou m.fl. 2005). Därför väljer jag här att undersöka strukturen av hyperlänkar mellan internationella högerextrema webbsidor, delvis med hjälp av automatiserade verktyg och delvis med hjälp av en semantisk innehållsanalys av webbsidorna. På det viset kommer det att vara möjligt att empiriskt analysera den globala spridningen av kollektiva handlingsramar och att kombinera dessa resultat med strukturen av kontakter mellan aktivistgrupper och sociala rörelser.

Med andra ord baseras analysen på antagandet att virtuella nätverk, som man kan hitta på internet, exempelvis hyperlänkarna mellan olika webbsidor, på något vis återspeglar de associativa strukturerna inom den internationella högerextremismen och utvecklingen och dynamiken inom den högerextrema diskursen. För att undersöka dessa samband, och få en insikt i dynamiken i de internationella högerextrema nätverkens associationer eller samarbeten, behöver vi en karta som pekar ut länkarna mellan olika noder i de högerextrema nätverkens onlineinnehåll och struktur (Zhou m.fl. 2005, s. I).

\section{Forskningsfrågor}

En del forskare antar att datorförmedlad kommunikation (computermediated communication, CMC) underlättar för sociala rörelser att överbrygga nationella gränser (Weinberg \& Kaplan 2003). Det antas då att åsiktsgemenskapen (eller attityden) blir viktigare än aktörernas nationella härkomst:

Deltagande mediaanvändning på nätet möjliggör för fler människor i olika länder att enkelt kommunicera direkt på ett sätt vi aldrig skådat tidigare - utan att

I. Även om många av dessa publikationer pekar på intensiva kontakter via hyperlänkar, vet vi inte särskilt mycket om den internationella högerextremismens onlinekontakter. "Kartläggningen av dessa onlinenätverk har hittills varit mycket begränsad, trots den växande betydelsen av extremisters och andra gruppers användning av hyperlänkar" (Ackland \& Gibson 2005, s. I). 
stater eller traditionella medier tillhandahåller eller förmedlar kommunikationen (MacKinnon 2004, s. 6).

Enligt den uppfattningen är det inte längre tid och rum som bestämmer diskursen (Illia 2002, s. 2).

Frågan är därmed om CMC ökar möjligheterna till kontakter över gränserna - fastän internationellt samarbete, vid första anblicken, verkar vara svårt att förena med de högerextremas nationalism? Vilka är de centrala aktörerna eller grupperna i nätverket och vad säger strukturen oss om hur den internationella högerextremismen integrerats? Har tidigare mer eller mindre distinkt åtskilda kollektiva identiteter blandats eller åtminstone börjat att referera till varandra? Och sist men inte minst, hur har nätverket förändrats under de senaste åren? För att besvara dessa frågor måste man (I) undersöka nätverkets strukturella egenskaper och (2) granska webbsidornas innehåll.

Nästa steg (3) är att kombinera resultaten (struktur och innehåll) och slutligen (4) ska vi undersöka urvalet longitudinellt.

\section{Undersökningsdesign och metodologi - (byperlänk-)nätverksanalys}

I artikeln föreslår jag en särskild strategi för att använda metoder som utformats inom social nätverksanalys för att studera internet. Samhällsvetenskaperna har många metoder som kan vara användbara för att studera nya medier, men har ändå inte använt dem förrän nu. Analysen av internetkommunikation erbjuder stora möjligheter för samhällsvetare eftersom den innehåller icke-responsiv data (non-responsive data), om man så vill "spår av kommunikationsakter”. Det är också möjligt att automatisera datainsamlingen genom att använda särskild mjukvara, så att en stor mängd data kan samlas på ett sätt som är pålitligt och möjligt att upprepa (Adamic m.fl. 2003).

Den sociologiska nätverksanalysen har rötter i klassisk sociologi, antropologi och lingvistik och är i allmänhet inriktad på "kartläggningen av de relationer som skapar sociala strukturer" (Turner I99I, s. 57I). Social nätverksanalys avser att identifiera strukturella egenskaper hos nätverk av sociala relationer, oavsett om de enheter vi intresserar oss för är individer, grupper, organisationer eller nationalstater (Wasserman \& Faust 1994; Freeman 1984, s. 343). 
Under de senaste decennierna har forskare skapat utvecklade, teoretiskt och empiriskt baserade modeller (t.ex. Smith-Lovin \& McPherson 1993; Wellman 1988). Den grundläggande logiken inom social nätverksanalys är ganska enkel: forskaren definierar en uppsättning av noder (det kan vara individuella aktörer, händelser, organisationer eller, i det här fallet, webbsidor publicerade av individuella aktörer, grupper eller aktivister), som utgör de sociala nätverken. Nästa steg är att samla data om relationerna mellan de enskilda noderna, till exempel överförandet av resurser eller, i det här fallet, hyperlänkar mellan de olika webbsidorna.

Enkelt uttryckt kan World Wide Web betraktas som en "systematisk samling av webbplatser som innehåller information" (Park 2002). Därigenom är hyperlänken "den grundläggande strukturella beståndsdelen”. En hyperlänk kan definieras som en teknisk lösning som möjliggör att en särskild hemsida (eller webbsida) kan länkas samman med en annan (Park 2003, s. 49). På det viset kan hyperlänken användas inte bara för att navigera World Wide Web och skaffa tillgång till specifik information, den kan också tjäna det sociala nätverkets syften. ${ }^{2}$ Under senare år har det ofta framhållits att strukturer av hyperlänkar kan utgöra en av de viktigaste källorna till information för samhällsvetenskapen när man studerar cyberrymden (Boudourides 2001; Ingwersen 1998; Scharnhorst 2003). Om vi antar att de enskilda nätadministratörernas beslut att hänvisa kan betraktas som subjektivt meningsfyllda, kan det till synes meningslösa kaoset av länkar mellan olika sidor ge oss en djupare insikt om kommunikationsstrukturerna hos olika aktörer inom World Wide Web (Garrido \& Halavais 2003).

Park och Thelwall (2003) betraktar hyperlänken som ”en ny framväxande social kommunikationskanal". Studiet av dessa nätverk är av största intresse för samhällsvetenskaperna, med tanke på att de har uppstått helt

2. Termen "webbplats" (t.ex. http://www.npd.de) är ett paraplybegrepp för det strukturerade nätverket av enkla "webbsidor" (t.ex. http://www.npd.de/html/I939/artikel/ detail/2068/) som innehåller innehållstyper (MIME-types) som text, filmer, bilder och så vidare. Dessa enskilda webbsidor knyts samman av hyperlänkar. Om dessa hyperlänkar knyter samman webbsidor inom en särskild webbplats, kallas de "interna hyperlänkar". Om de låter användaren hämta respektive "hoppa" till en annan webbplats (t.ex. från http://www.npd.de till http://www.aktion-widerstand.de) kallas de "externa hyperlänkar”. 
utan ingripande från forskarens sida och tillåter en mängd olika analytiska ansatser genom storskaliga studier av webbens struktur (Zimmermann m.fl. 2004, s. 7). I allmänhet kan sägas att en länk från en sida till en annan kan förstås som en symbol för solidaritet, i betydelsen ömsesidighet (Burris m.fl. 2000, s. 216).

Med andra ord kan man, enligt Foot med flera (2003), se mönstret av hyperlänkar mellan politiska aktörer inom World Wide Web som en "underförstådd, nätverkad politisk diskurs".

Det skulle ta för lång tid och det skulle vara för osäkert att söka upp ett stort antal webbsidor manuellt. Det är en av onlineforskningens fördelar att det är möjligt att använda särskild mjukvara för att göra det arbetet. Det gör det möjligt att samla och analysera en enorm mängd data på jämförelsevis kort tid. Mjukvara som kan användas för att utforska hyperlänkstrukturen inom World Wide Web är lätt åtkomlig: en "robot" (även kallad "webbspindel", web spider eller web crawler på engelska) är ett dataprogram som "automatiskt genomkorsar nätets hypertextstruktur genom att hämta ett dokument och återkommande hämta alla dokument som det däri länkas till”. 3 Om webbspindeln ges en särskild URL (uniform resource locator), till exempel http://www.example.com, utvinner den alla interna och externa länkar inom den domänen. Sedan utvinner den alla refererade webbsidor tillsammans med hyperlänkarna inom dessa domäner. Den här sortens datainsamling kan betrakta som ett "snöbollsurval" (Schnell, Hill \& Esser 1999; Zimmermann m.fl. 2004).

För att hitta hemsidor som kunde leda oss ut till den högerextrema rörelsen på World Wide Web, använde jag mig av olika sidor från deras motståndare eller från statliga myndigheter. Utgångspunkt för spindeln var 250 URL-adresser från internationella högerextrema webbsidor. Efter att jag hämtat mer än en halv miljon URL-adresser, stoppades datainsamlingen och URL-adresserna reducerades till de allmänna domänerna: Huvudenheten bestod av 20000 olika webbsidor. Nästa steg var att slumpmässigt välja ut 750 webbsidor som, enligt en ganska översiktlig innehållsanalys, samlades i fördefinierade kategorier (Wiederer 2007). Alla dessa sidor verkade inte vara kopplade till den radikala eller extrema

3. Hämtat från http://www.robotstxt.org/faq/what.html (I2 november 2004). 
högern, så urvalet reducerades. ${ }^{4}$ Till slut bestod det återstående urvalet av 440 webbsidor från olika högerextrema grupper i 27 länder. De flesta av webbsidorna kom från USA eller Tyskland, men det fanns också sidor från åtskilliga europeiska länder och även ett antal sydamerikanska och östasiatiska aktörer.

\section{Tabell I. Fördelningstabell för ideologi enligt nationalitet, procent av nationellt värde ( $n$ )}

\begin{tabular}{|c|c|c|c|c|c|c|c|}
\hline & Tyskland & USA & $\begin{array}{l}\text { Öst- } \\
\text { europa }\end{array}$ & $\begin{array}{l}\text { Central- } \\
\text { och Syd- } \\
\text { europa }\end{array}$ & $\begin{array}{c}\text { Resten av } \\
\text { världen }\end{array}$ & $\begin{array}{l}\text { Nord- } \\
\text { europa }\end{array}$ & Totalt \\
\hline $\begin{array}{l}\text { Kristen } \\
\text { fundamentalism }\end{array}$ & & $\begin{array}{l}6,60 \\
\text { (10) }\end{array}$ & & & $\begin{array}{r}\mathrm{IO}, \mathrm{OO} \\
(\mathrm{I})\end{array}$ & & $\begin{array}{l}2,50 \\
(I I)\end{array}$ \\
\hline Periferi $^{*}$ & $\begin{array}{r}2,60 \\
(5)\end{array}$ & $\begin{array}{r}2,60 \\
(4)\end{array}$ & $\begin{array}{r}5,60 \\
(\mathrm{I})\end{array}$ & $\begin{array}{r}2,20 \\
(\mathrm{I})\end{array}$ & & & $\begin{array}{l}2,50 \\
(I I)\end{array}$ \\
\hline $\begin{array}{l}\text { Förnekande av } \\
\text { förintelsen }\end{array}$ & $\begin{array}{r}\mathrm{I}, \mathrm{OO} \\
(2)\end{array}$ & $\begin{array}{r}\text { I I,30 } \\
(\mathrm{I} 7)\end{array}$ & $\begin{array}{r}\text { I I }, \text { IO } \\
(2)\end{array}$ & $\begin{array}{r}8,70 \\
(4)\end{array}$ & $\begin{array}{r}\mathrm{IO}, \mathrm{OO} \\
(\mathrm{I})\end{array}$ & $\begin{array}{r}10,50 \\
(2)\end{array}$ & $\begin{array}{l}6,40 \\
(28)\end{array}$ \\
\hline Ku Klux Klan & & $\begin{array}{r}4,60 \\
(7)\end{array}$ & & & & & $\begin{array}{r}1,60 \\
(7)\end{array}$ \\
\hline $\begin{array}{l}\text { Hednisk/ } \\
\text { esoterisk religion }\end{array}$ & $\begin{array}{r}15,80 \\
(3 \mathrm{I})\end{array}$ & $\begin{array}{r}3,30 \\
(5)\end{array}$ & & $\begin{array}{r}2,20 \\
(\mathrm{I})\end{array}$ & & & $\begin{array}{l}8,40 \\
(37)\end{array}$ \\
\hline Nynazism & $\begin{array}{r}28,10 \\
(55)\end{array}$ & $\begin{array}{r}\text { I } 8,50 \\
(28)\end{array}$ & $\begin{array}{r}33,30 \\
(6)\end{array}$ & $\begin{array}{r}2 \mathrm{I}, 70 \\
(\mathrm{IO})\end{array}$ & $\begin{array}{r}20,00 \\
(2)\end{array}$ & $\begin{array}{r}57,90 \\
(\mathrm{I} I)\end{array}$ & $\begin{array}{l}25,50 \\
(I I 2)\end{array}$ \\
\hline NSBM $^{* *}$ & $\begin{array}{l}8,20 \\
(\mathrm{I} 6)\end{array}$ & $\begin{array}{r}4,00 \\
(6)\end{array}$ & $\begin{array}{r}5,60 \\
(\mathrm{I})\end{array}$ & $\begin{array}{r}8,70 \\
(4)\end{array}$ & & $\begin{array}{r}10,50 \\
(2)\end{array}$ & $\begin{array}{l}6,60 \\
(29)\end{array}$ \\
\hline $\begin{array}{l}\text { Subkultur/ } \\
\text { skinheadkultur }\end{array}$ & $\begin{array}{r}\mathrm{I} 5,80 \\
(3 \mathrm{I})\end{array}$ & $\begin{array}{r}20,50 \\
(31)\end{array}$ & $\begin{array}{r}38,90 \\
(7)\end{array}$ & $\begin{array}{r}32,60 \\
(15)\end{array}$ & & $\begin{array}{r}2 \mathrm{I}, \mathrm{IO} \\
(4)\end{array}$ & $\begin{array}{r}20,00 \\
(88)\end{array}$ \\
\hline Radikal höger & $\begin{array}{r}28,60 \\
(56)\end{array}$ & $\begin{array}{r}0,70 \\
(\mathrm{I})\end{array}$ & & $\begin{array}{r}23,90 \\
(\mathrm{II})\end{array}$ & $\begin{array}{r}40,00 \\
(4)\end{array}$ & & $\begin{array}{r}I 6,40 \\
(72)\end{array}$ \\
\hline Vit makt & & $\begin{array}{r}27,80 \\
(42) \\
\end{array}$ & $\begin{array}{r}5,60 \\
(\mathrm{I})\end{array}$ & & $\begin{array}{r}20,00 \\
(2)\end{array}$ & & $\begin{array}{r}10,20 \\
(45) \\
\end{array}$ \\
\hline Totalt & $\begin{array}{r}100,00 \\
(196)\end{array}$ & $\begin{array}{r}I 00,00 \\
(I S I)\end{array}$ & $\begin{array}{r}100,00 \\
(18)\end{array}$ & $\begin{array}{r}100,00 \\
(46)\end{array}$ & $\begin{array}{r}100,00 \\
(10)\end{array}$ & $\begin{array}{r}100,00 \\
(19)\end{array}$ & $\begin{array}{r}100,00 \\
(440)\end{array}$ \\
\hline
\end{tabular}

* Material som hör till den högerextrema miljöns periferi.

** Nationalsocialistisk black metal.

4. Detta är en generell nackdel med den automatiserade ansatsen: "begränsningarna i dagens webbspindelteknik för ofta in brus (ej relevanta webbsidor) i urvalet" (Zhou m.fl. 2005, s. 5). 


\section{Strukturella mönster i det högerextrema hyperlänknätverket 2006}

Den högerextrema rörelsen är, nationellt såväl som internationellt, tätt sammanknuten. Alla webbsidorna i urvalet är direkt eller åtminstone indirekt länkade till varandra och hör matematiskt sett till samma komponent. Nätverksstrukturen visar en hög grad av redundans och strukturell ekvivalens. Även om alla webbsidorna ligger inom samma komponent, finns det två större regionala segment som också är tätt sammanknutna. Figur I visualiserar hyperlänkstrukturen som den extraherades i januari 2006.

Figur I. Visualisering av urvalets nätverk $(n=440)$

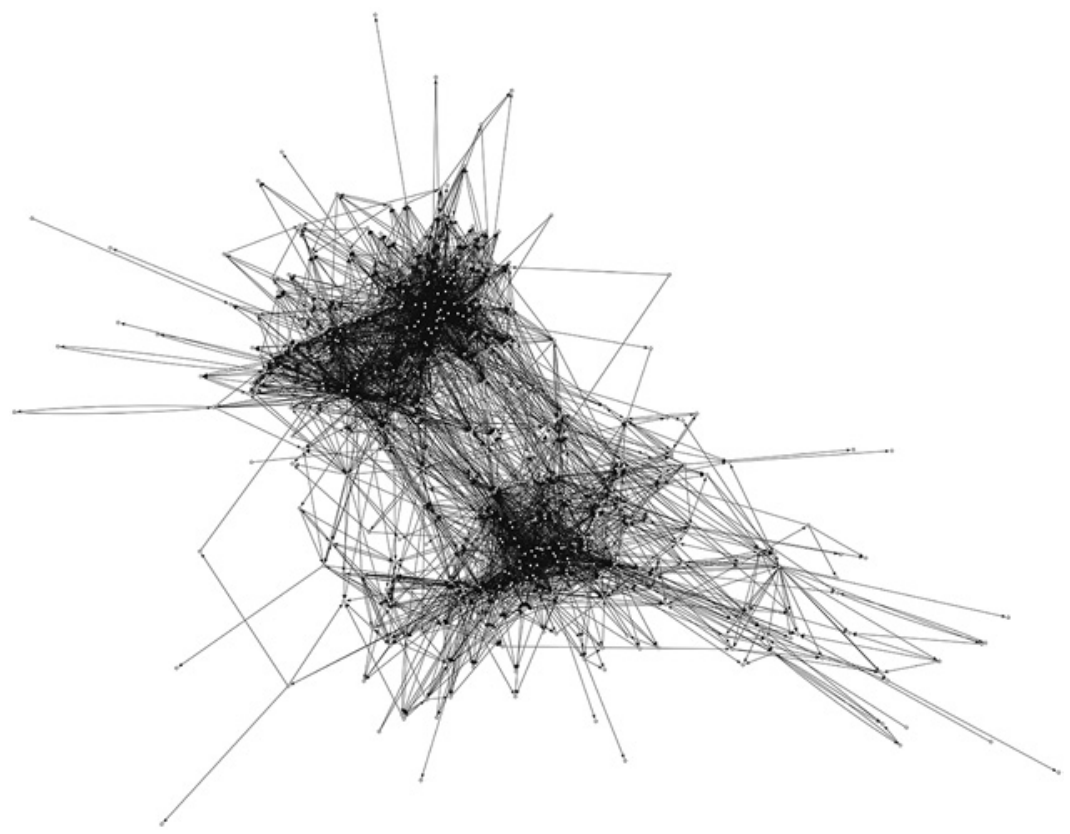

De 440 webbsidorna knyts samman av 3662 riktade hyperlänkar, vilket innebär att nätverkets densitet är omkring I,9 procent. Jämfört med de värden som Burris med flera (2000) rapporterade i sin analys av 80 huvudsakligen amerikanska webbsidor, kan detta värde verka ganska 
litet. Men forskarna fokuserade framför allt på det nätverk som skapats av vitmaktrörelsen (white supremacists), vilken bara är en särskild undergrupp av internationell högerextremism. Vi kommer senare se att de densiteter vi finner i den här studien utan vidare är jämförbara med andra studier.

Identifieringen av centrala och perifera aktörer i de sociala nätverken har från första början hört till de viktigaste uppgifterna inom nätverksforskningen (Borgatti \& Everett 200o). Centraliteten verkar hänga nära samman med prestige, så om en aktör refereras till av många andra webbsidor, kan vi i allmänhet anta att den har stor prestige (Brass I984). Sådana sidor kallas "auktoriteter". De har hög "ingrad” (indegree). Om, å andra sidan, en webbsida refererar till många andra sidor, är den en "hubb" som ger tillgång till många andra aktörer. Motsvarande mått, som kan tolkas som subjektiv "nätverksassociering", kallas "utgrad" (outdegree; eller "relative outdegree", om den normaliseras).

Nätverket behandlas analytiskt som ett stängt nätverk - det betyder att hyperlänkar som utgår från eller kommer från andra kluster inte har noterats, så det sammanlagda antalet utlänkar är det samma som antalet inlänkar. ${ }^{5}$ Det sammanlagda antalet utlänkar respektive inlänkar per sida är därmed 8,3.

Även om det sammanlagda antalet in- och utlänkar är detsamma, är deras fördelning oerhört snedvriden. Antalet inlänkar per sida varierar mellan o och 60 . De mest populära Io procenten $(n=44)$ av webbsidorna tar emot mer än en tredjedel av alla inlänkar (35,9 procent, $n=1316$ ). Den populäraste webbsidan är därmed National Alliance från USA. Tyska NPD fick 52 inlänkar, USA-baserade Stormfront fick 45 hänvisningar och det förintelseförnekande Institute for Historical Review fick 43. Fördelningen av utlänkar är ännu mer extrem: antalet länkar per aktör varierar mellan o och 9I. De mest "aktiva" Io procenten har 43,5 procent $(n=I 593)$ av alla utlänkar, de mest aktiva 20 procenten utgör omkring 65

5. Eftersom webben kan ses som en styrd graf, kan vi urskilja tre sorters relationer mellan noderna: ömsesidig, asymmetrisk och frånvarande (Polanco 2002, s. 5). Om webbsidan A länkar till webbsida B, kallas den länken "utlänk" för A och "inlänk" från B:s perspektiv; om webbsidan B också länkar till A, kallas detta ett "ömsesidigt länkande". Det finns förstås också möjligheten att ingen länk föreligger, och om sida A länkar till sig själv kallas det "egenlänk" eller "loop". 
procent. Den mest expansiva webbsidan är National Socialist Movement från USA, som har 9I utgående länkar. Det betyder att man kan få tillgång till omkring en femtedel av alla andra aktörer i urvalet från denna webbsida. Outpostguard erbjuder 82 länkar, tyska Tonstörung.net 69 . NPD och Stormfront är inte bara viktiga för rörelsen i termer av popularitet och som referens, dessutom visar de den högsta graden av "betweenness centrality"; ;e är ett slags "lokala" centrum.

Nätverket visar en skalinvariant fördelning av in- och utlänkar, men urvalets koefficient för potenslagen är något lägre än man skulle förvänta sig. Som figurerna 2 och 3 visar, är koefficienten -I,O3 för utgrad och - ,9I för ingrad. Det betyder att fördelningen är mindre skev. Det beror möjligen på att det finns fler centrala eller mellanliggande sidor än förväntat. ${ }^{7}$ Allt som allt uppvisar systemet drag av ett småskaligt nätverk (Wiederer 2007), vilket inte är förvånande när det gäller nätgemenskaper, men inte desto mindre är det en betydelsefull egenskap. ${ }^{8}$ Den övergripande nätverksanatomin är viktig "eftersom struktur alltid påverkar funktion" (Strogatz 20oI, s. 268). I ett skalinvariant eller "småskaligt" nätverk, är spridandet av idéer över regionala och ideologiska gränser mycket enkelt, även om hyperlänkar inte direkt transporterar information (Barabási 2003).

Det genomsnittliga geodesiska avståndet, det genomsnittliga antalet steg den kortaste vägen mellan ett slumpmässigt utvalt par webbsidor inom nätverket, är 3,7, vilket betyder att varje nåbar webbsida kan nås

6. Betweenness centrality är ett mått för att beskriva mellanliggande positioner.

7. Bortsett från det måste man tänka på att fördelningen påverkas av undersökningens perspektiv. Vi fokuserar här på ett urval av relationellt associerade webbplatser. Men i verkligheten refererar dessa noder vanligtvis också till noder som finns utanför det här systemet, förutom att de länkar till några udda aktörer. I den här omgivningen är distributionen av in- och utlänkar ännu mycket mer skev. Koefficienterna för potenslagen är mer eller mindre väntade, om in- och utlänkarna på dessa webbplatser hämtas av en större sökmotor som Google eller Alexa Internet.

8. Till en början karakteriseras ett småskaligt nätverk av starkt sammanknutna kluster av noder. Dessa klickar är i sin tur inte isolerade från varandra, utan knyts löst samman av olika "hubbar", till exempel aktörer som inte bara är medlemmar av en enda klick utan har olika kontakter med andra undernätverk. Det innebär att småskaliga nätverk å ena sidan i genomsnitt uppvisar en kort minsta steglängd och en hög kluster-koefficient. Därigenom kan varje nod nås från nästan alla andra noder i nätverket via ett litet antal steg (Watts \& Strogatz 1998). 
från varje annan nåbar webbsida i urvalet genom att klicka sig genom i genomsnitt 3,7 sidor.

Figur 2. Linjär regression: frekvens enligt rang (rank) (log-log-skala) - utgrad $(n=440)$

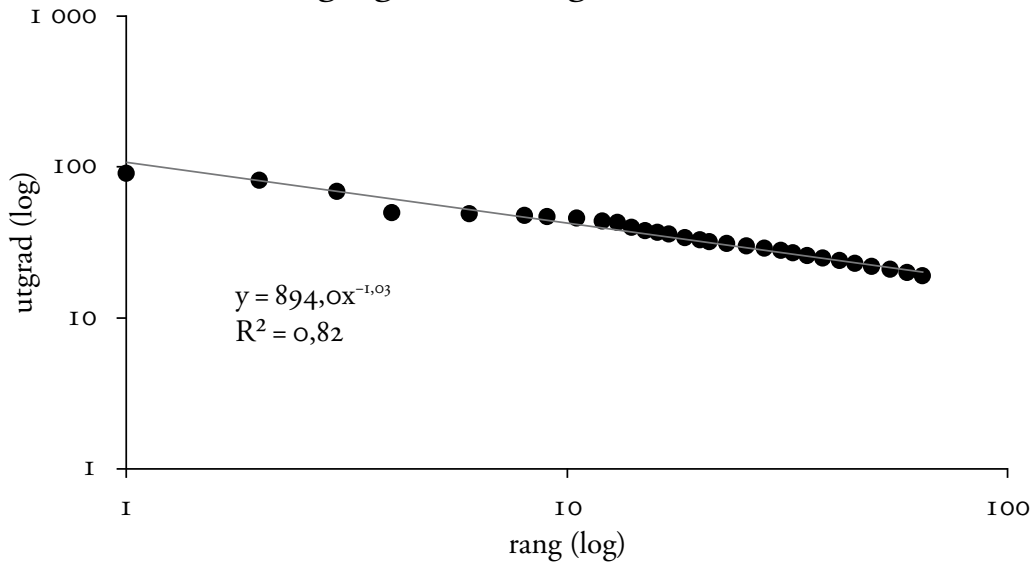

Figur 3. Linjär regression: frekvens enligt rang (rank)

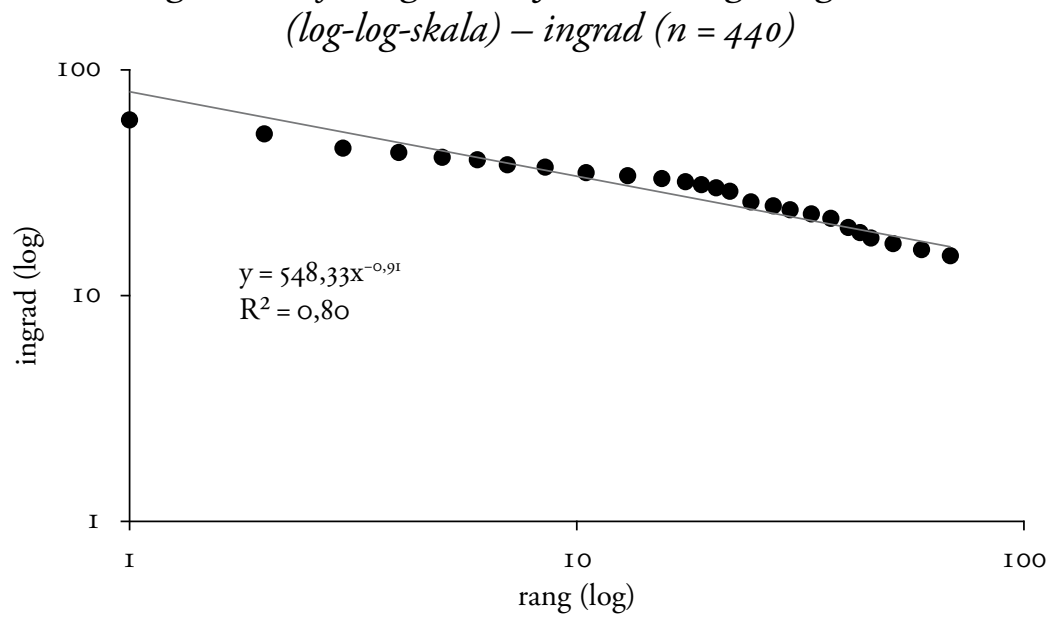

Efter att vi betraktat de enskilda aktörernas popularitet, kommer den följande analysen att handla om hur de nationella och ideologiska under- 
grupperna binds samman. ${ }^{9}$ För att testa hypotesen att användningen av CMC överskrider nationella och ideologiska gränser, var det nödvändigt att klassificera urvalets webbsidor enligt nationellt ursprung och ideologi och sedan kontrollera den relativa densiteten i nätverksstrukturen mellan dessa kategorier. ${ }^{10}$ Det förvånar inte att de nationella undergrupperna är tätare sammanknutna än genomsnittligt i nätverket $\left(\mathrm{R}^{2}=0,0 \mathrm{6}\right.$; justerad $\mathrm{R}^{2}=$ o,oI6; $\left.\mathrm{p}<0, \mathrm{OOI}\right) .{ }^{\text {II }}$ Den högsta densiteten finns mellan de nordeuropeiska webbsidorna, där den är nästan 20 procent. Dessa aktörer är inte bara sammanknutna på nationell nivå, de är även väl anknutna till amerikanska sidor och, i lite mindre utsträckning, till öst- och centraleuropeiska sidor. Intressant nog är referenserna till eller från tyska sidor få. Tabell 2 visar intensiteten i hyperlänkarna mellan aktörer med olika ursprung.

Tabell 2. Nätverksstruktur efter ursprung. Densitet inom och mellan kluster (i procent)

\begin{tabular}{l|ccccccc|} 
& Tyskland & USA & Östeuropa $\begin{array}{c}\text { Central- } \\
\text { och } \\
\text { Sydeuropa }\end{array}$ & $\begin{array}{c}\text { Resten av } \\
\text { världen }\end{array}$ & $\begin{array}{c}\text { Nord- } \\
\text { europa }\end{array}$ \\
\hline Tyskland & 3,5 & 0,3 & $0, \mathrm{I}$ & 0,6 & 0,3 & 0,5 \\
USA & 0,3 & 5,0 & I,3 & I,7 & 2,9 & 2,3 \\
Östeuropa & 0,2 & I,6 & 4,6 & I,9 & 0,0 & 2,9 \\
Central- och Sydeuropa & 0,7 & I, & I, & 3,0 & 2,0 & 2,2 \\
Resten av världen & 0,4 & $2, \mathrm{I}$ & 0,6 & $\mathrm{I}, \mathrm{I}$ & 7,8 & 3,2 \\
Nordeuropa & 0,7 & 4,6 & 2,6 & 2,9 & 3,2 & $\mathrm{I9,6}$ \\
\hline
\end{tabular}

* De markerade cellerna visar värden över nätverkets genomsnitt ( $\geq \mathrm{I}, 9$ procent).

9. I en konventionell social nätverksanalys, där noderna till exempel är människor eller organisationer, kan man inte rekommendera att jämföra undergrupper med olika storlek. Man kan förvänta sig att densiteten hos kontakterna i de större undergrupperna är mindre än i undergrupper med ett mindre antal fall. Men i en virtuell omgivning, spelar det inte så stor roll (Burris m.fl. 2000, s. 233).

Io. För detaljer om klassifikationsschemat, vänligen se Wiederer (2007).

II. ANOVA-densitets-modell "variable homophily". Denna blockmodell testar antagandet att "varje diagonal cell (det vill säga förbindelser inom grupp I, inom grupp 2 och inom grupp 3) skiljer sig från alla förbindelser utanför gruppen" (Hanneman \& Riddle 2005, kap. I8). 
Tabell 3. Nätverksstruktur efter ideologi.

Densitet inom och mellan kluster (i procent) ${ }^{*}$

\begin{tabular}{|c|c|c|c|c|c|c|c|c|c|c|}
\hline & 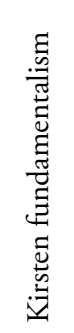 & : & 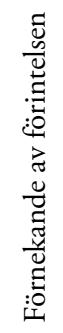 & $\begin{array}{l}\underset{\Xi}{\Xi} \\
\ddot{\Xi} \\
\vec{\Xi} \\
\vec{\Xi}\end{array}$ & 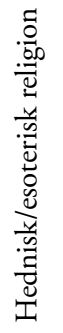 & 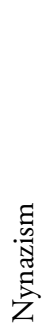 & $\begin{array}{l}\sum_{n} \\
\text { Z }\end{array}$ & 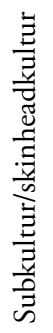 & 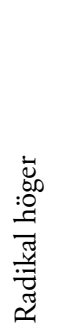 & $\begin{array}{l}\frac{\ddot{y}}{\tilde{\Xi}} \\
\stackrel{\Xi}{5}\end{array}$ \\
\hline $\begin{array}{l}\text { Kristen } \\
\text { fundamentalism }\end{array}$ & 10,9 & 2,5 & 5,2 & 2,6 & 0,0 & $\mathrm{I}, \mathrm{O}$ & 0,0 & $\mathrm{I}, \mathrm{I}$ & 0,0 & 2,8 \\
\hline Periferi & 0,0 & 4,6 & I, 6 & 0,0 & 0,3 & 0,7 & 0,0 & 0,0 & 2,9 & 0,6 \\
\hline $\begin{array}{l}\text { Förnekande av } \\
\text { förintelsen }\end{array}$ & 3,3 & 5,2 & $22, \mathrm{I}$ & $\mathrm{I}, 5$ & 0,6 & $\mathrm{I}, 4$ & 0,0 & 0,5 & 0,8 & $5, \mathrm{I}$ \\
\hline Ku Klux Klan & 2,6 & 2,6 & I, 5 & I I,9 & 0,4 & $\mathrm{I}, \mathrm{O}$ & 0,0 & $\mathrm{I}, 8$ & 0,0 & 3,8 \\
\hline $\begin{array}{l}\text { Hednisk/esoterisk } \\
\text { religion }\end{array}$ & 0,0 & $\mathrm{I}, \mathrm{O}$ & 0,4 & 0,4 & 4,2 & 0,2 & 0,9 & 0,4 & 0,5 & $\mathrm{O}, \mathrm{I}$ \\
\hline Nynazism & $\mathrm{I}, \mathrm{I}$ & $\mathrm{I}, 4$ & 4,2 & $\mathrm{I}, \mathrm{O}$ & $\mathrm{I}, 2$ & 4,9 & 0,7 & 2,2 & 3,0 & $3, \mathrm{I}$ \\
\hline $\mathrm{NSBM}^{* *}$ & 0,0 & 0,0 & $\mathrm{O}, \mathrm{I}$ & 0,0 & $\mathrm{I}, 6$ & 0,8 & $7, \mathrm{I}$ & $\mathrm{I}, 6$ & 0,4 & 0,6 \\
\hline $\begin{array}{l}\text { Subkultur/ } \\
\text { skinheadkultur }\end{array}$ & $\mathrm{I}, \mathrm{I}$ & 0,3 & 0,7 & 2,8 & 0,6 & $\mathrm{I}, 7$ & $\mathrm{I}, 2$ & 3,5 & 0,5 & $\mathrm{I}, 6$ \\
\hline Radikal höger & 0,0 & $\mathrm{I}, 3$ & 0,3 & 0,0 & 0,2 & $\mathrm{I}, 4$ & $\mathrm{O}, \mathrm{I}$ & 0,2 & 3,0 & 0,2 \\
\hline Vit makt & 3,2 & 4,2 & 7,7 & 2,5 & $\mathrm{I}, \mathrm{O}$ & 1,9 & 0,0 & $\mathrm{I}, 3$ & 0,7 & 7,9 \\
\hline
\end{tabular}

* De markerade cellerna visar värden över nätverkets genomsnitt ( $\geq \mathrm{I}, 9$ procent).

** Nationalsocialistisk black metal.

Bilden för de ideologiska undergrupperna i tabell 3 ser likadan ut på övergripande nivå: sammanknytningen inom undergrupperna är, i nästan alla fall, högre än mellan undergrupperna $\left(R^{2}=0,017\right.$; justerad $R^{2}=0,017$; 
$\mathrm{p}<$ O,OOI). ${ }^{\mathrm{I2}}$ Detta slags "självrefererande" är ännu starkare än bland de nationella undergrupperna. På motsvarande sätt är nätverkets densitet delvis förhöjd mellan de olika ideologiska lägren.

Värdena i kolumnerna visar hur många webbsidor av en viss kategori som refereras av webbsidorna i radernas kategorier. Höga värden kan indikera att den ideologiska gruppen i kolumnerna är starkt uppskattad av ett visst ideologiskt läger i raderna. Värdena hos ett ideologiskt läger i raderna motsvarar den andel av webbsidorna som de länkar till i kolumnernas kategorier.

Den högsta interna korslänkningen finns bland de webbsidor som ägnar sig åt att förneka förintelsen, med lite mer än 22 procent av sidorna. De följs med nästan I2 procent av Ku Klux Klans och med strax under II procent av de kristna fundamentalisternas sidor. Lite mindre, men ändå intensivt sammanlänkade är webbsidorna från vitmaktrörelsen (7,9 procent) och black metal-scenen (7,I procent). Sammanlänkningen inom de andra grupperna varierar mellan 3 och 5 procent.

De inbördes relationerna mellan de olika kategorierna uppvisar ganska distinkta mönster: Uppenbarligen är några av de ideologiska undergrupperna nära sammanknutna med varandra. De formerar någon form av kluster. Särskilt de webbsidor som tillhör kristna fundamentalister, förnekare av förintelsen och vitmaktrörelsen samt, i lite mindre utsträckning, $\mathrm{Ku}$ Klux Klan, är nära sammanbundna; ett nätverk av huvudsakligen amerikanska webbsidor. I USA verkar rörelsen domineras av organisationer och aktivister från vitmaktrörelsen, som är anmärkningsvärt inriktade på att sälja hatrock å ena sidan och att distribuera och översätta historierevisionism å den andra. I Europa verkar som kontrast den nynazistiska rörelsen dominera. De transnationella bryggorna är hatrocksförsäljare och, vilket är värt att lägga märke till, förnekare av förintelsen.

Musikscenen spelar en nyckelroll för den internationella integrationen av extremhögern. Detta gäller både på användar- och producentnivån. Många gränsöverskridande samarbeten mellan högerextrema organisationer och grupper beror inte minst på parternas ekonomiska intressen. Musikscenen är på det viset i konstant förändring och diversifieras ständigt; den kan knappast reduceras till folksånger och skinheadmusik.

I2. ANOVA-densitets-modell "variable homophily". 
Som Karmasyn med flera (2000) påpekar har förintelseförnekarna etablerat ett system av intensiva ömsesidiga referenser för att öka sin trovärdighet. De sträver efter att uppfattas som ett vetenskapligt sammanhang:

Förintelseförnekelse, som kokett refererar till sig själv som förintelserevisionism, har efter två årtionden av propaganda utvecklats till det främsta ideologiska kittet mellan de olika hatgrupperna under 1990-talet. Förnekandet, som ytligt sett ser ut som ett svårbegripligt pseudovetenskapligt bestridande av det väldokumenterade nazistiska folkmordet under andra världskriget, är en kraftfull konspirationsteori som förenar annars olikartade ytterlighetsrörelser (som Liberty Lobby, olika Klan-fraktioner, nynazister, Aryan Nations och andra identitetsrörelser, rasistiska skinnskallar, etc.) (Anti-Defamation League 1996).

Ett lite annorlunda mönster uppvisas av de nynazistiska webbsidorna: nynazisterna refererar till förnekare av förintelsen och representanter för den franska "nya högern" (Nouvelle Droite) för att ge sina egna utsagor mer vikt och trovärdighet, men det finns också speciella länkar till sidor som tillhör vitmakt- och skinheadrörelserna. Den nynazistiska scenen visar alltså upp kontakter med hårt tatuerade och mer subkulturella grupper.

\section{Högerextremt innehåll på internet - en semantisk analys}

För att komplettera resultaten från analysen av hyperlänkarna med en innehållsanalys, verkar det naturligt att välja en ansats som refererar till fenomenets relationella aspekter. I det följande kommer därför de strukturella associationerna mellan de högerextrema aktivisterna på World Wide Web att knytas till "diskursens nivå", med hjälp av semantiska nätverk av nyckelord (Halavais 2003, s. 8). Analysen av de semantiska nätverken används i allmänhet för att systematiskt fånga de sociala fältens "kognitiva" strukturer (Danowski 1982; Monge \& Eisenberg 1987). Förintelseförnekarnas lögner är välkända för oss och vi har mängder av kunskap om den världsbild som presenteras i den nynazistiska propagandan. Men tills vidare vet vi inte mycket om förändringsdynamiken hos de högerextrema ideologierna, de ömsesidiga influenserna från nationella, kulturella och även språkliga gränser, eller om dynamiken i hur informationen sprids i virtuella nätverk. 
Till skillnad från många textanalytiska metoder som söker utforska den innehållsliga strukturen i individuella fall, strävar en nätverksansats efter att avtäcka "metastrukturen" hos olika sorters dokument. Ansatsen kan anses "programmatiskt ytlig", eftersom den är en delvis automatiserad procedur av mönsterigenkänning som tillåter snabb och korrekt genomgång av betydande mängder ostrukturerat datamaterial. Den storskaliga kartläggningen av innehållet tillåter kvantifiering och visualisering av "semantiska nätverk", vilket skulle kunna återspegla associationsstrukturer inom högerextrema ideologier och föreställningar.

Eftersom urvalet lingvistiskt sett är så sammansatt, är det knappast möjligt att ens till hälften göra en meningsfull textanalys. Därför delades urvalet upp i två delar, en engelsk- och en tyskspråkig.

Som ett första steg fick en så kallad "text spider" automatiskt utvinna alla ord på samtliga av urvalets webbsidor. Sedan indexerades orden och sorterades enligt frekvens. De 50 ord som förekom mest på varje sida fungerade som indikatorer för sidans särskilda semantiska profil. Skapandet av ett dubbelt nätverk tjänar till att utforska systemets semantiska profil, baserat på likheterna och olikheterna inom textinnehållet på olika webbsidor. För att på ett effektivare sätt fånga associationerna mellan nyckelorden, omformas det dubbla nätverket till två enkla nätverk, av vilka det ena relateras till raderna och det andra till kolumnerna i den ursprungliga tvådimensionella matrisen. Därmed finns två möjliga analysperspektiv:

de numeriska metoderna är försök att fånga ansamlandet av aktörer som förts samman utifrån händelser; händelser som förts samman utifrån aktörers samtida närvaro; och de därav uppkomna "knippena" av aktörer/händelser (Hanneman \& Riddle 2005, kap. I7).

Först ska vi undersöka i vilken mån nyckelorden återfinns samtidigt på olika webbsidor. Detta gör det möjligt att identifiera kluster av nyckelord som utmärker särskilda grupper av webbsidor. 
Tabell 4. Klusteranalys av nyckelord $(n=220)$

\begin{tabular}{|c|c|c|c|}
\hline Kluster I & Kluster 2 & Kluster 3 & Kluster 4 \\
\hline album & anti & antifa & germanen \\
\hline alliance & aryan & arbeit & germanische \\
\hline america* & christ* & ausländer & gott \\
\hline blood & control & band* & leben \\
\hline book* & god & berlin & literatur \\
\hline british & government & brd & odin \\
\hline canada & group & bush & partei \\
\hline $\mathrm{cd}$ & hate & $\mathrm{cdu}$ & politik \\
\hline children & history & demo & recht \\
\hline country & hitler & demokratie & reich \\
\hline crime & holocaust & demonstration & religion \\
\hline death & iraq & deutsch* & runen \\
\hline download & israel $^{*}$ & ende & spd \\
\hline english & jesus & euro* & staat \\
\hline fact & jew* & freiheit & thor \\
\hline folk & law & geschichte & usa \\
\hline free & lord & gästebuch & verlag \\
\hline front & military & hartz & $\operatorname{volk}^{*}$ \\
\hline german* & money & information* & welt \\
\hline honour & nazi & irak & zeitung \\
\hline immigration & police & kameraden & \\
\hline life & political & kameradschaft & \\
\hline media & power & kinder & \\
\hline metal & race & krieg & \\
\hline movement & racial & kultur & \\
\hline $\mathrm{mp} 3$ & social & land & \\
\hline music & state* & lieder & \\
\hline news & story & menschen & \\
\hline public & united & musik & \\
\hline radio & war & nachrichten & \\
\hline records & whites & nation* & \\
\hline rights & world & npd & \\
\hline rock & & politisch* & \\
\hline shirt & & sachsen & \\
\hline shop & & stadt & \\
\hline skinhead & & stimme & \\
\hline skrewdriver & & system & \\
\hline socialist & & termine & \\
\hline support & & widerstand & \\
\hline
\end{tabular}


Kluster ett handlar huvudsakligen om hatrock, mp3-filer och så vidare. Det representerar högerextrem näthandel och musikförsäljning. Det andra klustret återspeglar den amerikanska vitmaktrörelsen, som domineras av historierevisionistiskt tänkande, beundran för historisk nationalsocialism och konspirationsteorier. Det tredje klustret domineras av den tyska nynazistiska diskursen och den europeiska intellektuella extremhögern och det fjärde och sista klustret domineras av hedniskt innehåll och esoterism. Det befinner sig i utkanten av den högerextrema scenen. Särskilt nordisk mytologi verkar ha ett starkt inflytande på delar av rörelsen. Den tjänar till att överskrida den nationalistiska och nationalsocialistiska retoriken och legitimera hat och våld. Även fast det finns avsevärda skillnader i ideologi mellan de olika regionala och ideologiska undergrupperna, verkar den högerextrema rörelsen ha hittat en gemensam ideologisk grund, en allmänt omfattad känsla för verklighet och handlingar:

\footnotetext{
Våra resultat tyder på att nationalism, religion och definitioner av ansvarsfullt medborgarskap är sammanflätat med ras på ett sätt som skapar en kollektiv identitet för dessa grupper, deras medlemmar och sympatisörer. Dessutom använder de sig av förklaringssystem som för varje upplevt samhällsproblem tillhandahåller en specifik lösning. Främst, [...] visar resultaten hur tolkningen av de påstådda grunderna till och de föreskrivna lösningarna på olika problem är systematiskt länkade med varandra (Adams \& Roscigno 2005, s. 759).
}

Många av de olika aktörerna ser sig själva som delar av en internationell rörelse och antisemitism verkar fungera som ett förenande element i den internationella diskursen. Medan den tyska agendan vimlar av främlingsfientlighet och den amerikanska av rasism, är det det gemensamma hatet mot "judar" som håller rörelsen samman, över varje nationsgräns. Antisemitiska attityder begränsar nationalismens inflytande och fungerar som legitimering för att bekämpa de egna regeringarna, som påstås ha infiltrerats av "judarna” och deras "en värld"-ideologi. Diskursen 2005 dominerades av konspirationsteorier, som en följd av II september-attackerna. I diskussionerna om Irakkriget och invasionen i Afghanistan, gav den högerextrema rörelsen intrycket av att vara engagerad i antikrigsaktivism. I allmänhet är högerextremismen alltmer benägen att ta över retorik från medborgarrättsrörelser och vänsterradikalism ("autonom nationalism", "nationell anarkism"). 
Figur 4 illustrerar de semantiska likheterna mellan de olika webbsidorna, baserat på en aktör-till-aktör-matris. Den har räknats fram genom en multidimensionell skalningsalgoritm (MDS), en teknik som möjliggör en visualisering av likheter och olikheter hos nätverkens noder. Ju mer lika två sidors semantiska profil är, desto större är (den analytiska) kontakten mellan de båda webbsidorna.

\section{Figur 4. Semantiska likheter mellan IIo högerextrema webbsidor}

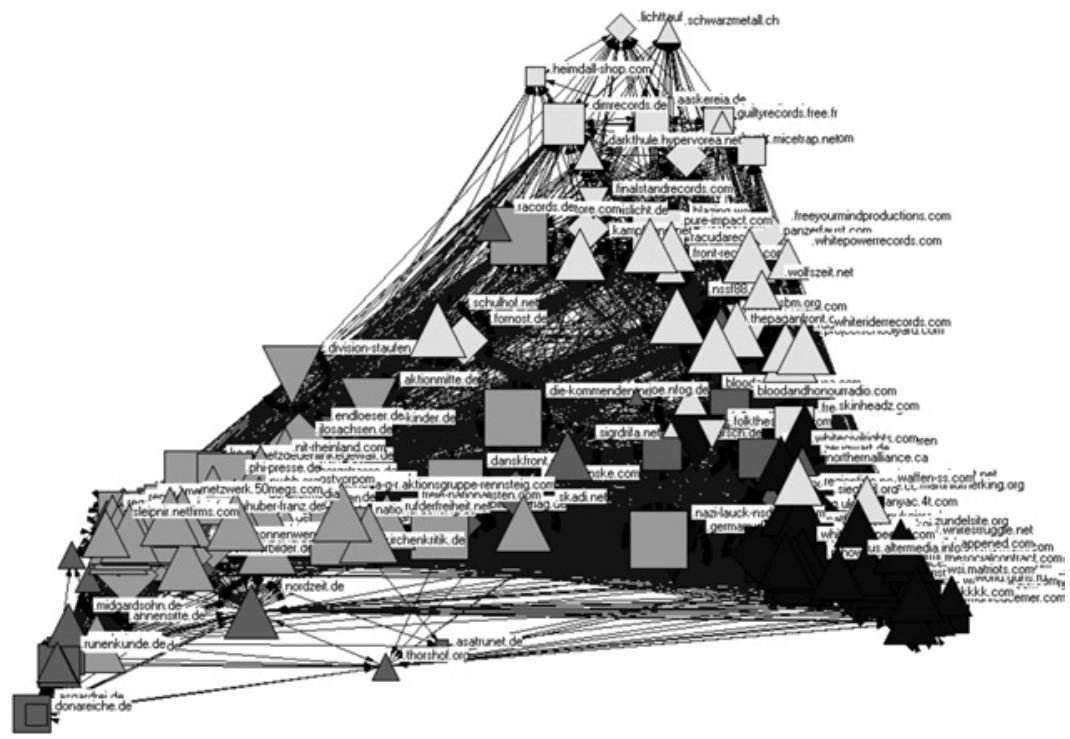

De semantiska associationerna återspeglas i ett korslänkningsmönster som påminner om hyperlänkstrukturen. Det finns fyra tätt sammanknutna kluster av webbsidor med liknande semantiska profiler och webbsidorna inom dessa kluster tillhör tendentiellt en särskild undergrupp inom den högerextrema rörelsen. Den högsta nivån av semantisk överensstämmelse kan hittas i klustret av amerikanska webbsidor. Klustret av huvudsakligen tyska webbsidor uppvisar en jämförbar nivå av överensstämmelser, även om koherensen verkar vara lite lägre. Den tredje gruppen omfattar hatrocksförsäljare, nationalsocialistisk black metal och skinnskallar, vilket understödjer antagandet att skinnskallarna kan ses som ett separat slags 
rörelse som bara tillfälligtvis kan mobiliseras av högerextrema partier eller hatgrupper. Angeläget för dem verkar snarare vara musik, alkohol och våld. Det fjärde klustret består huvudsakligen av hedniska sidor, esoterism eller sidor om nordisk mytologi. Denna kombination är klart mindre koherent än de andra. Dessa sidor kan bara delvis hänföras till den högerextrema scenen, med tanke på att en del av dessa aktörer kanske inte ens är medvetna om att de tjänar som en referens för den extrema högern.

Den uppenbarligen distinkta semantiska och kulturella klyvning som återspeglas i resultatet från klusteranalysen får inte skymma de tydliga begreppsmässiga likheterna mellan de olika grupperna. Alla nyckeltermer hos de 220 sidorna formerar en enda, starkt sammanlänkad komponent, fastän inga översättningar eller anpassningar har gjorts.

Huvudresultatet från den här proceduren var att de semantiska kopplingarna var ganska lika hyperlänkkontakterna. Denna effekt var starkare än de effekter som uppmättes i de (artificiellt) skapade undergrupperna ideologi och nationalitet. Fastän densiteten inom hyperlänknätverket är klart lägre $(4,5$ procent; $n=220)$ än i nätverket av semantiska likheter (37,9 procent), finns det en hög probabilitet för "matchning" mellan de två olika nätverken (länkar som inte riktats!). ${ }^{13} \mathrm{Om}$ det finns en länk mellan två webbsidor i hyperlänknätverket, är sannolikheten omkring 65 procent för att det finns en länk mellan dessa båda webbsidor även i det semantiska nätverket, och tvärtom. Detta resultat stödjer antagandet att de sociala nätverken uppvisar liknande egenskaper. ${ }^{14}$

\section{Nätverkets utveckling - ett longitudinellt perspektiv på hyperlänkstrukturen}

För att fördjupa analysen gjordes ett försök att undersöka nätverksstrukturens utveckling ur ett longitudinellt perspektiv under de senaste fem åren. Den ursprungliga planen var att gå tillbaka till alla de 440 webbsidorna och att komplettera data från studien i januari 2006 med data

I3. För att jämföra de olika nätverken, var det nödvändigt att behandla länkar som oriktade.

I4. Grupper eller individer tenderar att associeras med andra som på olika sätt är (eller verkar vara) som dem själva. 
från januari 20II. Därigenom hade det blivit möjligt att få ett grepp om skillnaderna mellan det gamla och det senare nätverket. Men det fanns ett betydande problem med det försöket: bara 230 av de tidigare 440 webbsidorna kunde utan problem återfinnas 20II. De flesta av de andra sidorna låg av olika orsaker nere; de hade till exempel hackats, gjorts om eller, majoriteten, tagits ner från webbhotellet. Å ena sidan är detta det första resultatet av den nya analysen: oppositionen mot de högerextrema grupperna verkar, åtminstone enligt en första blick, vara ganska effektiv; å andra sidan var det nödvändigt att ändra strategi för undersökningen.

Under dessa omständigheter beslöt jag att fokusera på en kärna av webbsidor i "hjärtat" av det högerextrema nätverket på internet och mäta de möjliga förändringarna i hyperlänkstrukturen hos dessa aktörer, vilket innebär att analysen särskilt intresserar sig för kontakterna mellan de tyska och de amerikanska webbsidorna. Ett slumpmässigt urval om 80 webbsidor hämtades från poolen av fortfarande tillgängliga webbsidor, 40 från USA och 40 skapade av tyska aktivister. Om man tar hänsyn till att studien från 2006 använde en datainhämtningsansats för att utforska den grundläggande strukturen hos det högerextrema nätverket på World Wide Web, och därför använde ett ganska detaljerat klassificeringsschema, blev det nu nödvändigt att justera klassificeringsmönstren. För att uppnå hanterbara och jämförbara grupper med det här ganska lilla antalet fall, gjordes ett försök att utveckla ett bredare schema som för samman några av de klasser som användes tidigare och tydligt åtskilja de olika ideologiska lägren inom den högerextrema scenen i Tyskland och USA.

De tyska webbsidorna klassificerades som "nynazism" (till exempel nätverket av så kallade Kameradschaften eller, vilket är mer kontroversiellt, några NPD-avdelningar), " radikal höger" (särskilt representanter från den tyska intellektuella högerextremismen i traditionen från den franska "nya högern"), "förnekande av förintelsen" (skribenter eller institut som förnekar förintelsen som ett historiskt faktum) och ett kluster av sidor som hör till den mer subkulturella delen av högerextremismen (till exempel skinnskallar eller hatrocksförsäljare och hatrocksband). Alla dessa kategorier kan och kommer alltså också att användas för klustret av sidor från USA, även om man kan notera att det i några avseenden finns slående transnationella skillnader även inom dessa kluster, vilket beror på att den socio-kulturella bakgrunden ser annorlunda ut. Den "radikala högern" består av extremt 
nykonservativa eller rasistiska grupper eller publikationer, som Council of Conservative Citizens eller American Renaissance, som vid första anblicken verkar udda jämförda med sina tyska motsvarigheter. Men närmare betraktade liknar de varandra på många sätt, visar överensstämmande intressen och uppvisar ett ganska intellektuellt habitus - ibland verkar den radikala högern anknyta till det övriga samhället. För att korrekt beskriva den högerextrema rörelsen i USA, behöver vi en ytterligare klass som inte har någon given motsvarighet $\mathrm{i}$ Tyskland, nämligen webbsidorna hos vitmaktrörelsen (white supremacists). I den här studien refererar termen till högerextrema rörelser i USA som skiljer sig åt vad gäller historisk utveckling och doktrin, men som i dag knappast kan skiljas åt (till exempel identitetsrörelsen eller Ku Klux Klan) (Reid \& Chen 2007, s. I82; Gerstenfeld m.fl. 2003; Gustavson \& Sherkat 2004).

För att utforska utvecklingen hos det högerextrema nätverket inom och mellan de båda länderna måste man skapa två nätverk, ett för 2006 och ett för 20II. Det äldre nätverket mellan de utvalda webbsidorna kan lätt utvinnas ur den tidigare studiens data. Det nyare nätverket utvanns från webben i januari 20II, med hjälp av exakt samma metod som när länkarna genomsöktes 2006, vilket redan beskrivits (för detaljer, se Wiederer 2007). Efter att webbsidorna (eller noderna) sammanförts i kluster efter ursprung och det klassificeringsschema som nämndes ovan, kunde densiteten av hyperlänkar inom och mellan dessa olika kluster kvantifieras för varje år. Fokus ligger på skillnaderna mellan 20II års nätverk jämfört med exakt samma aktörers nätverk fem år tidigare. Dessa skillnader kan förhoppningsvis ge oss några insikter om dynamiken i hur det högerextrema nätverket utvecklats på internet.

År 2006 var 80 webbsidor sammanknutna via 339 hyperlänkar, vilket resulterar i en övergripande densitet på 5,4 procent, eftersom "ett binärt nätverks densitet utgörs av det totala antalet förbindelser delat med det totala antalet möjliga förbindelser” (Borgatti m.fl. 2002). Fem år senare, 20II, knöts samma uppsättning webbsidor samman av 479 hyperlänkar, densiteten var alltså 7,6 procent. Figurerna 5 och 6 visualiserar denna ökning med I40 hyperlänkar som knyter samman webbsidorna i urvalet. ${ }^{\text {I5 }}$

I5. Webbsidorna från inhemska extremistgrupper i USA visas som trianglar riktade nedåt, medan de tyska grupperna är de rundade fyrkanter som huvudsakligen återfinns på figurernas högra sida. 
ARKIV | NR 2 | DET VITA FÄLTET II

Figur 5. Nätverk av 80 webbsidor från USA och Tyskland 2006

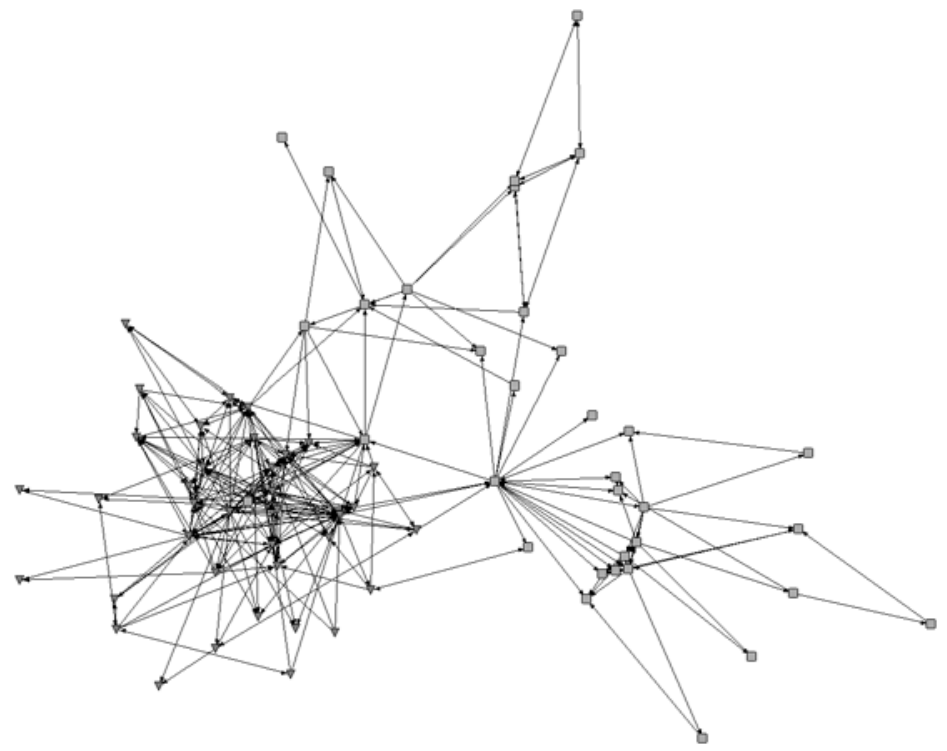

Figur 6. Nätverk av 80 webbsidor frän USA och Tyskland $20 I I$

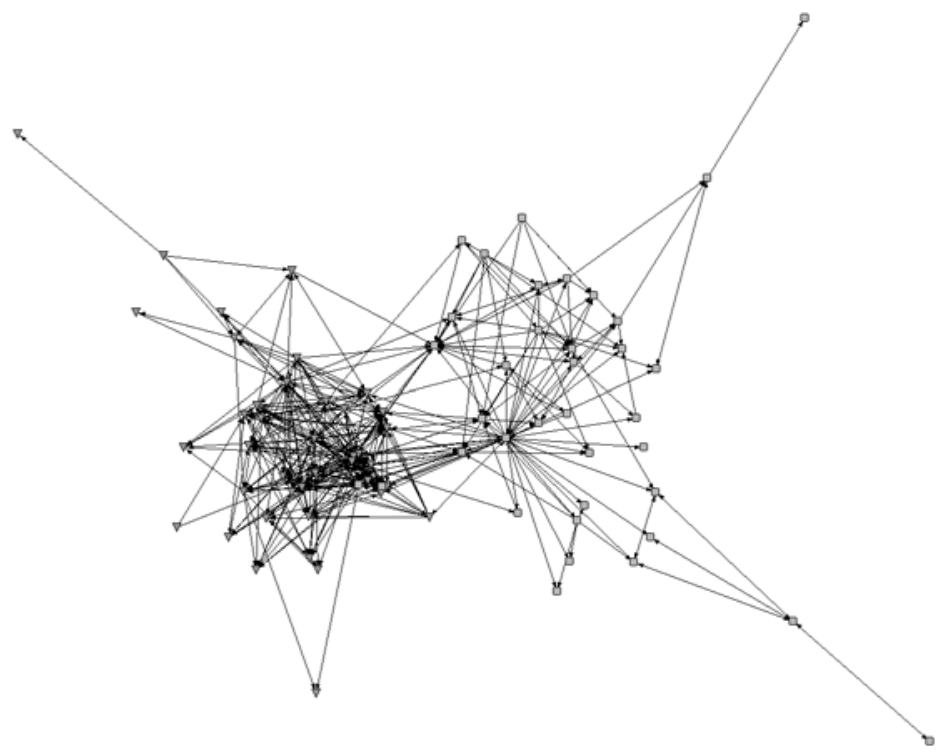


För att förstå denna övergripande ökning, måste vi titta närmare på fördelningen av de nya länkarna bland de kluster vi definierat. I termer av ursprung finns en del belägg för att densiteten ökade inom och mellan de båda klustren. Som tabell 5 och 6 visar ökade sammanlänkningen hos de tyska sidorna från 6,0 till 7,4 procent, men ökningen är betydligt större bland de amerikanska aktörerna: sidorna bands samman av 205 hyperlänkar 2005, 20II var de 290. Detta innebär en ökning i densiteten på omkring 5,4 procent på bara fem år. Fastän sammanbindningen mellan aktivisterna i de båda länderna också ökar, är den ökningen betydligt mindre. De tyska referenserna till amerikanska sidor steg bara med o,2 procentenheter, till I,9. Samtidigt steg referenserna från amerikanska aktivister till deras tyska motsvarigheter från 0,9 till 2,7 procent.

\section{Tabell s och 6. Relationer mellan webbsidor frain Tyskland och USA} 2006 och 20II, sammanlänkning $i$ procent $(n=80)$

\begin{tabular}{|l|cc|}
2006 & Tyskland & USA \\
\hline Tyskland & 6,0 & I,7 \\
USA & 0,9 & I 3,I \\
\hline
\end{tabular}

\begin{tabular}{|l|cc|} 
2OII & Tyskland & USA \\
\hline Tyskland & 7,4 & I,9 \\
USA & 2,7 & I 8,6 \\
\hline
\end{tabular}

Tabell 5 och 6 visar att den ökande sammanknytningen inom den högerextrema rörelsen på nätet inte är jämt fördelad mellan alla delar av nätverket. De ökande kontakterna mellan 2006 och 20 I kan särskilt observeras inom grupper som var starkt sammanbundna redan 2006. I USA verkar det som att vitmaktrörelsen knyts närmare till de nynazistiska organisationerna. I själva verket formerar de båda lägren nu ett gemensamt kluster, både vad avser deras nätverksintegrering och deras doktriner. Dessa resultat svarar mot den analys som Reid och Chen (2007) gjorde. Trots allt verkar vitmaktrörelsen vara den mest aktiva gruppen: mellan 2006 och 201 I genererade webbadministratörerna i denna grupp 48 nya hyperlänkar som riktades till andra kluster i detta urval och i6 nya länkar inom det egna lägret. Enbart I3 av de 48 nya länkarna till andra riktas till det amerikanska nynazistiska klustret. Å andra sidan tenderar de nynazistiska grupperna att skapa nya hyperlänkar till vitmaktrörelsen. Båda klustren är intensivt knutna till förintelseförnekarnas webbsidor. Därigenom ökar referenserna till vitmaktsidorna något, medan de som riktas till nynazister i USA minskade. 
ARKIV | NR 2 | DET VITA FÄLTET II

Tabell 7. Nätverksdensitet efter ursprung och doktrin (i procent) 2006

\begin{tabular}{|c|c|c|c|c|c|c|c|c|c|c|}
\hline & \multicolumn{4}{|c|}{ Tyskland } & \multicolumn{5}{|c|}{ USA } \\
\hline & & 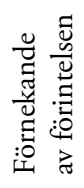 & 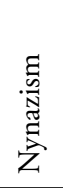 & 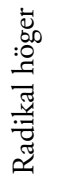 & $\begin{array}{l}\frac{\vec{Z}}{\vec{Z}} \\
\frac{\vec{z}}{\vec{\theta}} \\
\overrightarrow{\vec{n}}\end{array}$ & 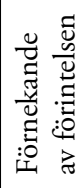 & 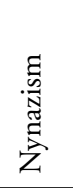 & 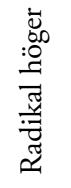 & $\begin{array}{l}\frac{\vec{Z}}{\vec{Z}} \\
\frac{\vec{y}}{0} \\
\vec{\Xi}\end{array}$ & 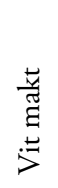 \\
\hline \multirow{4}{*}{ 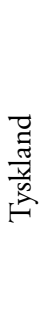 } & $\begin{array}{l}\text { Förnekande } \\
\text { av förintelsen }\end{array}$ & 50,0 & 0,0 & 5,6 & 0,0 & IOO,O & 25,0 & I 8,8 & I 6,7 & 33,3 \\
\hline & Nynazism & $3, \mathrm{I}$ & I9,2 & 3,8 & $\mathrm{I}, 6$ & 0,0 & 0,8 & 0,0 & 0,0 & 0,0 \\
\hline & Radikal höger & 2,8 & 0,0 & 9,5 & 0,0 & 3,7 & 0,0 & 0,0 & 0,0 & 0,0 \\
\hline & Subkultur & 0,0 & 0,0 & $\mathrm{I}, 4$ & 0,0 & 0,0 & 0,0 & 0,0 & 0,0 & 0,0 \\
\hline \multirow{5}{*}{$\underset{ら}{\mathscr{ら}}$} & $\begin{array}{l}\text { Förnekande } \\
\text { av förintelsen }\end{array}$ & 33,3 & 0,0 & 0,0 & 0,0 & 50,0 & 4,2 & 4,2 & 0,0 & 5,6 \\
\hline & Nynazism & 25,0 & $\mathrm{I}, 6$ & 0,0 & 0,0 & 45,8 & I $6, \mathrm{I}$ & $\mathrm{I} 2,5$ & I 5,3 & 22,9 \\
\hline & Radikal höger & 0,0 & 0,0 & 0,0 & 0,0 & 12,5 & $\mathrm{I}, 6$ & 28,6 & 2,8 & 13,5 \\
\hline & Subkultur & 0,0 & 0,7 & 0,0 & 0,0 & 3,7 & 5,6 & 2,8 & I 2,5 & 7,4 \\
\hline & Vit makt & 8,3 & 0,5 & 0,9 & 0,0 & 25,0 & I I, 5 & 24,0 & 6,5 & $2 \mathrm{I}, 2$ \\
\hline
\end{tabular}

Förintelseförnekarnas webbsidor formerar det mest intensivt sammanbundna klustret, nationellt såväl som transnationellt. Fastän tidigare studier visade att dessa aktörer tenderar att länka enbart till andra "revisionister", och inte refererar till andra kluster, indikerar resultaten från den här analysen att detta bara delvis är sant. I själva verket är de starkt länkade till varandra men stundtals refererar de även till andra ideologiska läger. Under de senaste fem åren har särskilt de amerikanska representanterna i det klustret ökat sina kontakter till nynazistiska organisationer i Tyskland liksom i USA. I båda fallen ökade nätverksintensiteten med 4,2 procent. 
Tabell 8. Nätverksdensitet efter ursprung och doktrin (i procent) $20 I I$

\begin{tabular}{|c|c|c|c|c|c|c|c|c|c|c|}
\hline & \multicolumn{4}{|c|}{ Tyskland } & \multicolumn{5}{|c|}{ USA } \\
\hline & & 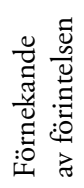 & 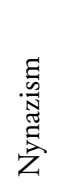 & 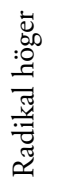 & $\begin{array}{l}\frac{\vec{Z}}{\vec{Z}} \\
\frac{\vec{z}}{0} \\
\vec{\Xi} \\
\dot{n}\end{array}$ & 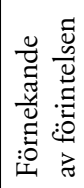 & 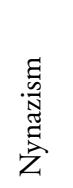 & 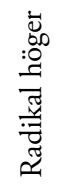 & $\begin{array}{l}\frac{\vec{Z}}{\vec{Z}} \\
\frac{\vec{z}}{0} \\
\vec{D} \\
\vec{n}\end{array}$ & 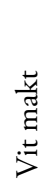 \\
\hline \multirow{4}{*}{$\frac{\vec{J}}{\frac{\vec{\pi}}{4}}$} & $\begin{array}{l}\text { Förnekande } \\
\text { av förintelsen }\end{array}$ & IOO,O & 0,0 & 0,0 & 0,0 & 83,3 & 31,3 & 12,5 & I I, I & 20,8 \\
\hline & Nynazism & 6,3 & 20,0 & 9,4 & $3, \mathrm{I}$ & 4,2 & 2,3 & $\mathrm{I}, 6$ & 0,0 & $\mathrm{I}, \mathrm{C}$ \\
\hline & Radikal höger & 2,8 & 2,8 & 7,8 & $\mathrm{I}, 4$ & 0,0 & 0,0 & 0,0 & 0,0 & 0,5 \\
\hline & Subkultur & 0,0 & 0,0 & $\mathrm{I}, 4$ & 0,0 & 0,0 & 0,0 & 0,0 & 0,0 & $\mathrm{O}, \mathrm{C}$ \\
\hline \multirow{5}{*}{$\underset{\omega}{\mathscr{b}}$} & $\begin{array}{l}\text { Förnekande } \\
\text { av förintelsen }\end{array}$ & 66,7 & 4,2 & 0,0 & 0,0 & 83,3 & 8,3 & 4,2 & 0,0 & 5,6 \\
\hline & Nynazism & $3 I, 3$ & 4,7 & 0,7 & 0,0 & 37,5 & 17,9 & I 8,8 & 6,9 & 29,2 \\
\hline & Radikal höger & 6,3 & 0,0 & 0,7 & 0,0 & 8,3 & $3, \mathrm{I}$ & $32, \mathrm{I}$ & 0,0 & I I, \\
\hline & Subkultur & 5,6 & $2, \mathrm{I}$ & 0,6 & 0,0 & $\mathrm{I} 4,8$ & 16,7 & 8,3 & 26,4 & $\mathrm{I} 2, \mathrm{C}$ \\
\hline & Vit makt & 33,3 & $2, \mathrm{I}$ & 2,8 & 0,0 & 44,4 & 25,0 & 37,5 & 8,3 & 33,3 \\
\hline
\end{tabular}

En annan intressant utveckling kan observeras i det subkulturella klustret $\mathrm{i}$ USA. Densiteten inom den gruppen ökade med I3,9 procent och referenserna till andra kluster ökade också, särskilt till förnekarna av förintelsen, de nynazistiska organisationerna och vitmaktrörelsen. Detta är intressant eftersom detta kluster innehåller hatrocks- och streetwear-försäljare liksom skinheadgrupper, och därmed representerar den amerikanska högerextremismens ungdomskultur.

Om det stora klustret av vitmaktgrupper och nynazister är den hårda kärnan i den inhemska terrorismen i USA, kan den "radikala högern" lokaliseras till periferin, närmare den politiska huvudfåran. Detta kluster 
mottar fler och fler länkar från rörelsens kärna, men länkar sällan tillbaka. Förmodligen försöker den hårda kärnans aktivister öka sitt anseende genom att länka till dem.

Förändringarna i den amerikanska delen av nätverket verkar, vid en första anblick, vara mycket större än i den tyska delen. Sammanbindningen har bara förändrats en aning, särskilt är densiteten i de olika klustren nästan oförändrad. Enbart det tyska nynazistiska nätverket verkar fortfarande vara särskilt engagerat i nätverkande. ${ }^{16}$ Vad de utgående länkarna angår, har sammanbindningen till vart och ett av de andra klustren i analysen ökat åtminstone en aning. Särskilt har länkarna till den tyska "intellektuella högern" (+5,6 procent) och till de amerikanska förintelseförnekarnas sidor (+4,2 procent) ökat under de senaste fem åren.

Sammantaget verkar de amerikanska inhemska extremistgrupperna vara betydligt tätare sammanbundna är sina tyska motsvarigheter. De mest sammanhållna grupperna 20II är de amerikanska förintelseförnekarna (83,3 procent), vitmaktgrupperna (33,3 procent) och den amerikanska radikala högern (32,I procent). Förutom de (alltför) små $(n=2)$ klustren av sidor från tyska förintelseförnekare (Ioo procent), visar de tyska nynazistiska grupperna den högsta graden av sammanlänkning.

Det visar sig också att de transnationella relationerna mellan tyska och amerikanska sidor nästan bara härrör från dessa båda kluster. Den radikala högern och det subkulturella klustret lägger knappast märke till de amerikanska aktivister som undersöks i den här studien. Å andra sidan visar amerikanska extremister ett ökande intresse för det tyska nynazistiska nätverket och förintelseförnekarnas sidor. Den tyska "intellektuella högern" verkar fånga vitmaktrörelsens intresse i allt större utsträckning.

Tillväxtdynamiken hos extremhögerns nätverk återspeglar till viss del den övergripande tillväxtdynamiken på World Wide Web. På grund av dess enorma storlek och komplexitet verkar World Wide Web vid första anblicken som en amorf ostrukturerad enhet, som är bortom detaljerad

I6. Det tyska nätverket av förintelseförnekare tas inte upp i det här sammanhanget på grund av att det lilla antalet fall $(n=2)$ kan leda till felaktiga tolkningar. Ökningen på 5o procent i nätverkets densitet beror på en länk mellan dessa båda organisationer. Icke desto mindre var det nödvändigt att hänvisa dem till ett separat kluster, eftersom de på många betydande sätt avviker från andra aktörer i Tysklands högerextrema rörelse. 
vetenskaplig beskrivning. Forskare trodde till en början att webbens tillväxtdynamik styrdes av slumpen. I dag vet vi att webben tvärtom är starkt strukturerad (Albert \& Barabási 200I; Broder m.fl. 2000; Kleinberg m.fl. 1999). Fördelningen av åtskilliga egenskaper hos World Wide Web, och hos internet i allmänhet, följer en potenslag (power law) i stället för en Poisson-fördelning, som man kunde ha misstänkt inom ramen för slumpvisa nätverk:

Potenslagar formulerar matematiskt det faktum att i de flesta verkliga nätverk har majoriteten av noderna bara ett fåtal länkar och att dessa många små noder samexisterar med ett fåtal stora hubbar, noder med ett onormalt högt antal länkar (Barabási 2003, s. 70).

En orsak till att det är den typen av strukturer som växer fram ligger i den tillväxtdynamik som uppstår i komplexa system byggda på utvalda kontakter (preferential attachment):

I längden följer vi alla samma omedvetna benägenhet att i större utsträckning länka till noder vi känner till, ofrånkomligen de som är mer sammanlänkade på nätet. Vi föredrar hubbar (Barabási 2003, s. 70).

Tendenser till detta tillväxtmönster kan också observeras i analysen av nätgemenskaper som det nätverk av högerextrema webbsidor som undersökts i den här studien. Många av de populäraste webbsidorna i nätverket är jämförelsevis gamla. De samlade hyperlänkar från andra sidor, vann uppmärksamhet från större sökmotorer (eller massmedier) och samlade ännu fler länkar, en "vinnaren tar allt"-dynamik, en självförstärkande process (Tsvetovat \& Carley 2005, s. 3). Stormfront, Institute for Historical Review, National Alliance och Resistance Records är sådana "auktoriteter" i det högerextrema nätverket på World Wide Web. En större tysk "auktoritet" är NPD:s webbsida. Under de senaste fem åren har den sidans popularitet ökat rejält. Vid en rankning av frekvensen av inlänkar kommer NPD 2006 som nummer fem, men 2011 som nummer två - med exakt samma antal inlänkar som Stormfront (I9 stycken). Den populäraste webbsidan enligt det sättet att mäta var Institute for Historical Review. En av de just nu mest intressanta webbsidorna är Altermedia 
som verkar ha starkast inflytande på nätverket, särskilt när det gäller transnationella kontakter.

\section{Sammanfattning av resultaten}

Det grundläggande syftet med den här undersökningen var att använda grafisk webbanalys för en sociologisk studie av nätgemenskaper. Med hjälp av en semiautomatisk ansats användes hyperlänksanalys och innehållsanalys för att kartlägga de strukturella och semantiska egenskaperna hos den högerextrema rörelsen på internet. Även om metoden har klara begränsningar (Park \& Thelwall 2003), är resultaten från denna och åtskilliga andra studier i allmänhet uppmuntrande (Reid \& Chen 2007; Burris m.fl. 2000; Zhou m.fl. 2005; Gerstenfeld m.fl. 2003; Tateo 2005; Wiederer 2007), eftersom alla dessa delvis varierande ansatser faktiskt visar jämförbara resultat.

De flesta av de tillgängliga studierna om högerextremisters användning av CMC visar att aktivister i ökande utsträckning använder internet som ett

kraftfullt verktyg för att underlätta rekrytering, nå en global publik, nätverka med andra extremister och för att sprida hatpropaganda som hjälper andra att ta steget till våld och terrorism (Zhou m.fl. 2005, s. 2).

Internet hjälper aktivister att genomföra en motståndsstrategi utan ledare, vilket betyder att individer eller grupper uppfattar sig själva som delar av en större rörelse men agerar på egen hand - utan att involveras i organisatoriska strukturer, i total anonymitet (Jones 2005).

Icke desto mindre anstränger sig i synnerhet många av de inhemska amerikanska extremistgrupperna att etablera virtuella gemenskaper för att mobilisera resurser, eftersom rutinoperationer, som insamling av pengar eller möten, skyddas av USA:s konstitution (Reid \& Chen 2007, s. I84).

Några av de tidigare nämnda studierna ger liksom den här artikeln insikter om hur det högerextrema nätverket på World Wide Web binds samman på en strukturell nivå. Även om den extrema högern vanligen beskrivs som en fragmenterad och splittrad rörelse, visar undersökningar som genomförts på senare år att det finns en ideologisk konvergens på nationell och även transnationell nivå (Burris m.fl. 2000, s. 23I). 
Burris med flera (2000), som analyserade hyperlänkstrukturen hos 80 webbsidor från vitmaktrörelsen med hjälp av metoder hämtade från social nätverksanalys, fann att de internationella banden var starkare bland grupper med särskilda intressen, som betonade sin intellektuella legitimitet, eller bland grupper som tematiserade kulturell identitet. Kontakterna var i allmänhet svagare bland grupper som konkurrerar om medlemmar eller kunder. Nätverket av högerextrema webbsidor var i någon mån isolerat från andra extremistgrupper och konservativa, men hyperlänkar mellan ungdoms- och vuxenorganisationer och propagandasatsningar från mindre öppet rasistiska grupper verkade underlätta rekryteringen. Reid och Chen (2007), som också analyserade hyperlänkstrukturen inom dessa organisationer, kunde identifiera flera nätgemenskaper, och visade att densiteten inom olika ideologiska undergrupper är betydligt högre än genomsnittet i nätverket. Men de hittade även några centrala sidor, som Stormfront, som överbryggade de strukturella klyftorna mellan de olika doktrinära lägren. Liksom Burris med flera (2000) kunde de sluta sig till att de uppkopplade kontakterna på ett signifikant sätt återspeglar de associationer som finns "nerkopplat" mellan dessa grupper (Reid \& Chen 2007, s. I84).

Resultaten från den här analysen bekräftar huvudsakligen de tidigare studierna. Rörelsen verkar ändå ha ett flertal inflytelserika centrum som uttrycks i tätt sammanknutna kluster av webbsidor, men dessa är långt ifrån isolerade från varandra. Det finns åtskilliga hubbar som håller rörelsen aktuell. Den småskaliga strukturen hos den internationella högerextremismen kan bidra till en kontinuerlig synkronisering. En semantisk analys av webbsidornas innehåll visar hur nära de olika grupperna befinner sig, ideologiskt och strategiskt. Onlinekommunikation minskade betydelsen av nationella gränser, men de är ändå en betydande faktor (Myers 2000, s. 2).

Det är bara bland historierevisionisterna som nationella gränser och språkskillnader helt verkar ha förlorat sin relevans. Men icke desto mindre finns det anmärkningsvärda kontakter mellan högerextrema grupper från olika nationer. Det finns ett antal kraftigt frekventerade onlineforum, som fungerar som "broar" i den internationella rörelsens diskurs.

En longitudinell analys visade att kontakterna inom och mellan flera olika nationella eller ideologiska kluster ökade på ett betydande sätt. 
Men medan många amerikanska sidor är relativt stabila och växande, lider de tyska extremisterna av en stark fluktuation bland sina webbsidor. De som driver dem måste ofta byta webbhotell eller helt avsluta sina aktiviteter på internet. Å andra sidan skapas nästan dagligen nya högerextrema internetsidor - som alltså ofta får ett väldigt "kort liv" (Bundesministerium des Innern 20I0, s. 59). Statens repression och aktiviteter från ideologiska motståndare räcker inte för att stoppa rörelsen vare sig på internet eller utanför, men de kan åtminstone med viss framgång hindra konsolideringen av en varaktig högerextrem gemenskap i den tyska cyberrymden.

\section{Slutsats och rekommendationer för ytterligare forskning}

Information, kommunikation och nätverksbyggande - internet erbjuder nästan obegränsade möjligheter för politisk aktivism. Egyptens ”Facebook-revolution" är bara ett slående exempel på dess potentiella politiska makt. Dessvärre är den digitala världens oräkneliga möjligheter även öppna för odemokratisk och främlingsfientlig aktivism. Även innan Anders Behring Breiviks politiskt inspirerade mördande i Norge 2OII var det uppenbart att den högerextrema nätpropagandan kan innebära allvarliga hot mot den offentliga sfären.

Den ökande populariteten för och den sociala verkan av politiska bloggar och de sociala nätverkens tjänster, som Facebook och Twitter, ökar intensiteten och dynamiken hos cyberaktivismen ännu mer. Det borde inte förvåna att det finns belägg för att högerextrema aktivister använder dessa tjänster intensivt. Om empirisk samhällsvetenskaplig forskning vill skapa sig kunskap om den utvecklingen är det ett gott råd att fullt ut använda de tekniska möjligheter som de nya medierna erbjuder. En kontinuerlig övervakning med hjälp av automatiska verktyg kan hjälpa oss att identifiera nya strategier och propagandaansträngningar från den högerextrema rörelsen på internet, den kan hjälpa oss att lägga märke till möjlig radikalisering av delar av rörelsen och identifiera "röda flaggor", där det är fara å färde. Eftersom högerextremistiskt innehåll

på internet ökar är det viktigt att vi utvecklar verktyg som möjliggör för forskare att kartlägga, analysera och förutsäga förändring och utveckling vad gäller extremisters och hatgruppers användning av nätet (Zhou m.fl. 2005, s. 2). 
Den sociala nätverksansatsen kanske bara är en ytterligare möjlighet att skaffa insikter i dynamiken i kollektiv handling och politisk aktivism, men i den digitala tidsåldern kan det vara en allt viktigare möjlighet - för att effektivt bekämpa högerextremism på internet måste vi ta hänsyn till cyberrymdens tekniska egenskaper och autonomi, så att vi kan undvika bakslag eller oavsedda (sido-)effekter. ${ }^{17}$

Men att kartlägga relationerna i cyberrymden är inte tillräckligt, ytterligare forskning behövs när det gäller frågan om i vilken utsträckning relationer och samarbete i verkliga livet påverkas av uppkopplade nätverk och vice versa. Vi behöver veta om högerextrem nätaktivism har "verkliga" konsekvenser och under vilka villkor en benägenhet till våld och symboliska uttryck för hat kan övergå i handling.

Trots allt får vi inte glömma att problemet med hatgrupper och hatpropaganda när allt kommer omkring har vuxit ut ur majoritetssamhället. Det är enkelt att fördöma öppet rasistiska åsikter, men det är ganska svårt att erkänna den vitt spridda men subtila vardagliga diskrimineringen och marginaliseringen av minoriteter. Ur det perspektivet kan censur av hatpropaganda vara en viktig del av symbolpolitiken i demokratiska samhällen, men det får inte avleda oss från att betrakta den mer eller mindre dolda vardagliga sociala marginaliseringen och förtalet. Att försvara det "öppna samhället" genom att förbjuda motbjudande och möjligen farliga åsiktsyttringar som hatpropaganda är definitivt nödvändigt och viktigt på många sätt, men det är absolut inte riskfritt.

\section{Översättning: Mats Deland, Paul Fuehrer och Thomas Hvitfeldt ${ }^{18}$}

\footnotetext{
I7. Exempelvis kan utbildning om vissa organisationer vara viktig för att informera allmänheten om tveksamt eller farligt innehåll på nätet, men just uppmärksamhet i massmedier gjorde att några av webbplatserna vann en betydande popularitet. På samma sätt kan det vara kontraproduktivt när antifascister i upplysningssyfte anger aktiva hyperlänkar - som genom de sökalgoritmer som används av de populära sökmotorerna kan "översättas" till popularitet.

I8. Översättning av citat: David Lindberg.
} 


\section{Referenser}

Ackland, Robert \& Gibson, Rachel K. 2005. Mapping Far-Right Political Party Networks on the WWW. Center for Social Research, Research School of Social Sciences, The Australian National University.

Adamic, Lada, Buyukkokten, Orkut \& Adar Eytan 2003. A Social Network Caught in the Web. First Monday 8, 6.

URL: http://firstmonday.org/htbin/cgiwrap/bin/ojs/index.php/fm/article/ view/I057/977 (I8 februari 2013)

Adams, Josh \& Roscigno, Vincent J. 2005. White Supremacists, Oppositional Culture and the World Wide Web. Social Forces 84, 2, s. 759-778.

Dor: http://dx.doi.org/I0.I353/sof.2006.000I

Albert, Réka \& Barabási, Albert-László 200I. Statistical Mechanics of Complex Networks. School of Mathematics, University of Minnesota and Department of Physics, University of Notre Dame.

Anti-Defamation League 1996. Holocaust Denial: An Online Guide to Exposing and Combating Anti-Semitic Propaganda.

URL: http://archive.adl.org/holocaust/print.asp (I8 februari 20I3)

Barabási, Albert-Lázló 2003. Linked. The New Science of Networks. Cambridge: Perseus Publishing.

Blumer, Herbert 1953 [1939]. Collective Behavior, i Lee, Alfred McClung (red.) New Outline of the Principles of Sociology. New York: Barnes \& Noble.

Borgatti, Stephen P. \& Everett, Martin G. 200o. Models of Core/Periphery Structures. Social Networks 2I, 4, s. 375-395.

DoI: http://dx.doi.org/Io.IoI6/So378-8733(99)ooor9-2

Borgatti, Stephen P., Everett, Martin G. \& Freeman, Linton C. 2002. Ucinet for Windows. Software for Social Network Analysis. Harvard: Analytic Technologies.

Boudourides, Moses A. 200I. New Directions of Internet Research. Paper presenterat vid konferensen ETK 200I - NTTS 200I i Hersonissos, Kreta, Grekland, I8-22 juni. URL: http://www.math.upatras.gr/ mboudour/articles/ir.pdf (I8 februari 2013)

Brass, Daniel J. 1984. Being in the Right Place: A Structural Analysis of Individual Influence in an Organization. Administrative Science Quarterly 29, 4, s. 518-539. DOI: http://dx.doi.org/IO.2307/2392937

Broder, Andrei m.fl. 2000. Graph Structure in the Web. Paper presenterat vid Ninth International World Wide Web Conference i Amsterdam. URL: http://www9.org/w9cdrom/160/160.html (I8 februari 2013)

Bundesministerium des Innern 20I0. Verfassungsschutzbericht 2009. Berlin.

Burris, Val, Smith, Emery \& Strahm, Ann 2000. White Supremacist Networks on the Internet. Sociological Focus 33, 2, s. 215-235. DoI: http://dx.doi.org/I0.I080/00380237.2000.1057II66

Danowski, James A. 1982. Computer-Mediated Communication: A Network-based Content Analysis using a CBBS Conference, i Burgoon, M. (red.) Communication Yearbook 6. Beverly Hills: Sage, s. 905-924. 
Foot, Kirsten A. m.fl. 2003. Analyzing Linking Practices: Candidate Sites in the 2002 US Electoral Web Sphere. Journal of Computer-Mediated Communication 8, 4. DoI: http://dx.doi.org/Io.IIII/j.I083-6IoI.2003.tboo220.x

Freeman, Linton C. 1984. Turning a Profit from Mathematics: The Case of Social Networks. The Journal of Mathematical Sociology 10, 3-4, s. 343-360. DoI: http://dx.doi.org/Io.Io8o/oo22250X.1984.9989975

Garrido, Maria \& Halavais, Alexander 2003. Mapping Networks of Support for the Zapatista Movement: Applying Social-Networks Analysis to Study Contemporary Social Movements, i McCaughey, Martha \& Ayers, Michael D. (red.) Cyberactivism. Online Activism in Theory and Practice. London: Routledge, s. I65-I84.

Gerstenfeld, Phyllis, Grant, Diana \& Chiang, Chau-Pu 2003. Hate Online: A Content Analysis of Extremist Internet Sites. Analyses of Social Issues and Public Policy 3, I, s. $29-44$. DOI: http://dx.doi.org/IO.IIII/j.I530-24I5.2003.00013.x

Gustavson, Aleta T. \& Sherkat, Darren E. 2004. Elucidiating the Web of Hate: the Ideological Structuring of Network Ties Among Right Wing Hate Groups on the Internet. Paper presenterat vid American Sociological Associations årsmöte.

Halavais, Alexander Campbell 2003. Networks and Flows of Content on the World Wide Web. Paper presenterat för International Communication Association i San Diego.

Hanneman, Robert A. \& Riddle, Mark 2005. Introduction to Social Network Methods. University of California, Riverside. URL: http://faculty.ucr.edu/ - hanneman/nettext (I8 februari 20I3)

Heitmeyer, Wilhelm 2002. Rechtsextremistische Gewalt, i Heitmeyer, Wilhelm \& Hagan, John (red.) Internationales Handbuch der Gewaltforschung. Wiesbaden: Verlag für Socialwissenschaften.

Illia, Laura 2002. Cyberactivism and Public Relations Strategy. New Dynamics and Relationship Rules. Masteruppsats, University of Lugano, Schweiz.

Ingwersen, Peter 1998. The Calculation of Web Impact Factors. Journal of Documentation 54,2 , s. 236-243.

DOI: http://dx.doi.org/Io.IIo8/EUMooooooooo7167

Jones, Calvert W. 2005. Online Impression Management: Case Studies of Activist Web Sites and their Credibility Enhancing Tactics during the Kosovo Conflict. School of Information Management and Systems, University of California at Berkeley.

Karmasyn, Gilles, Panczer, Gérard \& Fingerhut, Michel 200o. Le négationnisme sur Internet: Genèse, stratégies, antidotes. Revue d'histoire de la Shoah 170.

Kitschelt, Herbert \& McGann, Andrew J. 1995. The Radical Right in Europe. A Comparative Analysis. Ann Arbor: University of Michigan Press.

Kleinberg, Jon m.fl. 1999. The Web as a Graph: Measurements, Models, and Methods. Översikt till International Conference on Combinatorics and Computing. URL: http://www.cs.cornell.edu/home/kleinber/web-graph.ps (I8 februari 20I3)

Koopmans, Ruud 1996. Explaining the Rise of Racist and Extreme Right Violence in Western Europe: Grievance or Opportunities? European Journal of Political Research 30, 2, s. $185-216$.

DOI: http://dx.doi.org/Io.IIII/j.I475-6765.1996.tboo674.x 
Levin, Brian 2002. Cyberhate. A Legal and Historical Analysis of Extremists' Use of Computer Networks in America. American Behavioral Scientist 45, 6, s. 958-988. DOI: http://dx.doi.org/IO.II77/0002764202045006004

MacKinnon, Rebecca 2004. The World-Wide Conversation. Online Participatory Media and International News. The Joan Shorenstein Center on the Press, Politics and Public Policy, Working Paper Series, Harvard.

Minkenberg, Michael 1998. Die neue radikale Rechte im Vergleich. USA, Frankreich, Deutschland. Opladen: Westdeutscher Verlag.

Monge, Peter R. \& Eisenberg, Eric M. 1987. Emergent Communication Networks, i Jablin, Fredric M. m.fl. (red.) Handbook of Organizational Communication. Newbury Park: Sage.

Myers, Daniel J. 200o. Media, Communication Technology, and Protest Waves. Paper till konferensen Social Movements Analysis: The Network Perspective vid Ross Priory i Loch Lomond, Skottland, 22-25 juni.

URL: http://www.nd.edu/ -dmyers/lomond/myers.pdf (I8 februari 20I3)

Oliver, Pamela \& Myers, Daniel J. 2000. Networks, Diffusion, and Cycles of Collective Action. Paper till konferensen Social Movements Analysis: The Network Perspective vid Ross Priory i Loch Lomond, Skottland, 22-25 juni.

URL: http://www.nd.edu/ -dmyers/lomond/olivermy.pdf (I8 februari 20I3)

Park, Han Woo 2002. Examining the Determinants of Who is Hyperlinked to Whom: A Survey of Webmasters in Korea. First Monday 7, II.

URL: http://firstmonday.org/htbin/cgiwrap/bin/ojs/index.php/fm/article/ view/ıoo5/926 (I8 februari 2013)

Park, Han Woo 2003. Hyperlink Network Analysis: A New Method for the Study of Social Structure on the Web. Connections 25, I, s. 49-6I.

URL: http://www.insna.org/PDF/Connections/v25/2003_I-I-5.pdf (I8 februari 2013)

Park, Han Woo \& Thelwall, Mike 2003. Hyperlink Analyses of the World Wide Web: A Review. Journal of Computer-Mediated Communication 8, 4. DOI: http://dx.doi.org/IO.IIII/j.IO83-6IOI.2003.tboo223.x

Passy, Florence 2003. Social Networks Matter. But How?, i Diani, Mario \& McAdam, Doug (red.) Social Movements and Networks. Relational Approaches to Collective Action. Oxford: Oxford University Press.

Polanco, Xavier 2002. Clusters, Graphs, and Networks for Analysing Internet-Web Supported Communication within Virtual Community. Paper presenterat vid 7th International ISKO Conference i Granada, Spanien, IO-I3 juli.

Reid, Edna \& Chen, Hsinchun 2007. Internet-Savvy U.S. and Middle East Extremist Groups. Mobilization. An International Quarterly Review I2, 2.

Rucht, Dieter 2002. Rechtsradikalismus aus der Perspektive der Bewegungsforschung, i Grumke, Thomas \& Wagner, Bernd (red.) Handbuch Rechtsradikalismus. Opladen: Leske und Budrich Verlag.

Scharnhorst, Andrea 2003. Complex Networks and the Web: Insights From Nonlinear Physics. Journal of Computer-Mediated Communication 8, 4. DoI: http://dx.doi.org/IO.IIII/j.IO83-6IOI.2003.tboo222.x 
Schnell, Rainer, Hill, Paul B. \& Esser, Elke 1999. Methoden der empirischen Sozialforschung. 6 uppl. München: Oldenbourg.

Simon Wiesenthal Center 2002. Digital Hate 2002. Los Angeles (cd-rom).

Smith-Lovin, Lynn \& McPherson, J. Miller 1993. You Are Who You Know: A Network Approach to Gender, i England, Paula (red.) Theory on Gender/Feminism on Theory. Hawthorne: Aldine de Gruyter.

Strogatz, Steven H. 200I. Exploring Complex Networks. Nature 4IO, s. 268-276. DOI: http://dx.doi.org/IO.I038/35065725

Tateo, Luca 2005. The Italian Extreme Right On-line Network: An Exploratory Study Using an Integrated Social Network Analysis and Content Analysis Approach. Journal of Computer-Mediated Communication IO, 2.

DoI: http://dx.doi.org/IO.IIII/j.I083-6IOI.2005.tboo247.x

Tsvetovat, Maksim \& Carley, Kathleen M. 2005. Generation of Realistic Social Network Datasets for Testing of Analysis and Simulation Tools. School of Computer Science, Carnegie Mellon University, Pittsburgh.

Turner, John C. 1991. Social Influence. Buckingham: Open University Press.

Wasserman, Stanley \& Faust, Katherine 1994. Social Network Analysis. Methods and Applications. Cambridge: Cambridge University Press.

Watts, Duncan J. \& Strogatz, Steven H. 1998. Collective Dynamics of "Small-world" Networks. Nature 393, s. 440-442.

DOI: http://dx.doi.org/10.1038/30918

Weinberg, Leonard \& Kaplan, Jeffrey 2003. Right-Wing Extremism in the Western World and the Question of Globalism. Paper till konferensen Challenges to the New World order: Anti-globalism and Counter-globalism i Amsterdam, 30-3I maj. URL: http://socialhistory.org/sites/default/files/docs/weinberg.doc (I8 februari 2013)

Wellman, Barry 1988. Structural Analysis. From Method to Metaphor to Theory and Substance, i Wellman, Barry \& Berkowitz, Stephen D. (red.) Social Structures. A Network Approach. Cambridge: Cambridge University Press.

Whine, Mike 2004. Hate Groups' Use of the Net for Command and Control, i Bronkhorst, Suzette \& Eissens, Ronald (red.) Hate on the Net. Virtual Nursery for In Real Life Crime. Paris: International Network Against Cyberhate (INACH).

Wiederer, Ralf 2007. Zur virtuellen Vernetzung des internationalen Rechtsextremismus. Herbolzheim: Centaurus-Verlag.

Zhou, Yilu m.fl. 2005. U.S. Domestic Extremist Groups on the Web: Link and Content Analysis. Artificial Intelligence Laboratory, University of Arizona.

URL: http://www.w.icadl.org/intranet/papers/Zhou_Domestic_MainText.pdf (I8 februari 20I3)

Zimmermann, Ann, Koopmans, Ruud \& Schlecht, Tobias 2004. Political Communication on the Internet. Part 2: Link Structure among Political Actors in Europe. Berlin: Wissenschaftszentrum Berlin für Sozialforschung. 


\section{THOMAS MALM DEN OMÖJLIGA KEDJAN Människan och mångfaldens mönster}

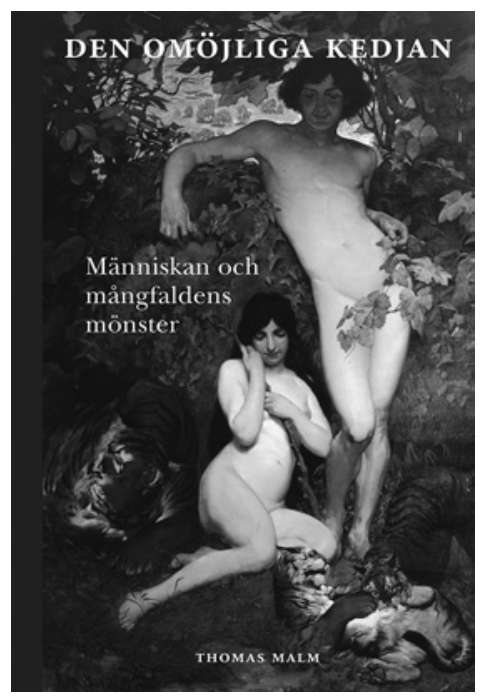

I alla tider har människor klassificerat växter, djur och varandra. Västerlänningar har sett sig själva såsom stående högt upp på en stege eller trappa, med de andra organismerna under sig, eller som en yttersta länk i "varandets stora kedja". Uttryck som "skapelsens krona", "den felande länken" och "civilisationens utkanter" blottar en världsbild som kan leda våra tankar fel och i sina värsta avarter har legitimerat rasbiologi och rasism.

Den omöjliga kedjan handlar om en av idéhistoriens mest grandiosa tanketraditioner, men till stora delar också om hopplösa idéer och mörka återvändsgränder. Med ett brett tvärvetenskapligt angreppssätt utforskar socialantropologen Thomas Malm olika aspekter av det fundamentalt mänskliga behovet av att indela, namnge och värdera omvärlden.

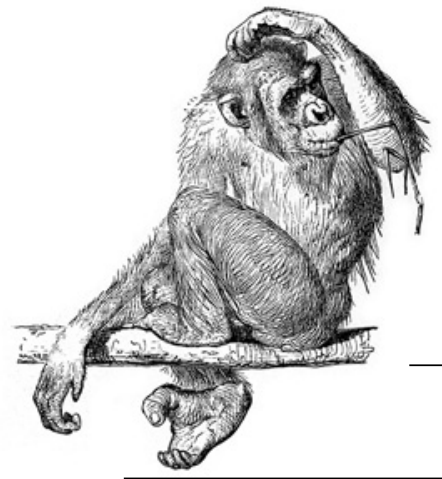

Arkiv förlag 2009, inbunden, 424 sidor

Alla som är intresserade av hur vi - vetenskapsmän lika väl som 'vanliga människor' ... - tänker om naturen och våra medmänniskor har mycket att hämta i hans bok.

Nils Uddenberg i Dagens Nyheter

„Läs mer om boken på www.arkiv.nu« 